\title{
Hydraulic Fracturing Stress Measurements at Yucca Mountain, Nevada, and Relationship to the Regional Stress Field
}

\author{
J. M. Stock, ${ }^{1}$ J. H. Healy, S. H. Hickman, ${ }^{1}$ and M. D. Zoback ${ }^{2}$ \\ Office of Earthquakes, Volcanoes, and Engineering, U.S. Geological Survey, Menlo Park, California
}

\begin{abstract}
Hydraulic fracturing stress measurements and acoustic borehole televiewer logs were run in holes USW G-1 and USW G-2 at Yucca Mountain as part of the Nevada Nuclear Waste Storage Investigations for the U.S. Department of Energy. Eight tests in the saturated zone, at depths from 646 to 1288 $\mathrm{m}$, yielded values of the least horizonital stress $S_{h}$ that are considerably lower than the vertical principal stress $S_{v}$. In tests for which the greatest horizontal principal stress $S_{H}$ could be determined, it was found to be less than $S_{v}$, indicating a normal faulting stress regime. The borehole televiewer logs showed the presence of long (in excess of $10 \mathrm{~m}$ ), vertical, drilling-induced fractures in the first $300 \mathrm{~m}$ below the water table. These are believed to form by the propagation of small preexisting cracks under the excess downhole fluid pressures (up to $5.2 \mathrm{MPa}$ ) applied during drilling. The presence of these drilling-induced hydrofractures provides further confirmation of the low value of the least horizontal stresses. A least horizontal principal stress direction of $\mathrm{N}^{\circ} 0^{\circ} \mathrm{W}-\mathrm{N} 65^{\circ} \mathrm{W}$ is indicated by the orientation of the drillinginduced hydrofractures $\left(\mathrm{N} 25^{\circ} \mathrm{E}-\mathrm{N} 30^{\circ} \mathrm{E}\right)$, and the orientation of stress-induced well bore breakouts in the lower part of USW G-2 $\left(\mathrm{N} 65^{\circ} \mathrm{W}\right)$. This direction is in good agreement with indicators of stress direction from elsewhere at the Nevada Test Site. The observed stress magnitudes and directions were examined for the possibility of slip on preexisting faults. Using these data, the Coulomb criterion for frictional sliding suggests that for coefficients of friction close to 0.6 , movement on favorably oriented faults could be expected. For coefficients of friction of 1.0, preexisting faults of all orientations should be stable. Laboratory studies on the Yucca Mountain tuffs, reported elsewhere, yield coefficients of friction ranging from 0.6 to 0.9 .
\end{abstract}

\section{INTRODUCTION}

In an area such as Yucca Mountain, Nevada Test Site, where a nuclear waste repository might be constructed [Winograd, 1981], a knowledge of the stress field is needed for the proper design of the repository and the evaluation of seismic stability and likelihood of motion on preexisting faults. Activities related to the construction and use of a nuclear waste repository, such as drilling and excavation, as well as the generation of heat by the stored waste, will change the local stress field to some degree. The magnitude of these changes can be estimated, but a knowledge of the preexisting tectonic stresses and their orientations is vital to prediction of how these additional imposed stresses will affect the tectonic stability of the repository area.

Previous workers have obtained a great deal of information about stress magnitudes and orientations in the Nevada Test Site (NTS) area. These data, summarized in part by Carr [1974] and Zoback and Zoback [1980], show that the NTS region currently exhibits both normal and strike-slip faulting, with a least horizontal principal stress direction varying from NW to WNW. Much of this stress information is poorly constrained; direct measurement of the current tectonic stress field using hydraulic fracturing and overcoring techniques had only been obtained at Rainier Mesa, in the northern part of NTS, about $40 \mathrm{~km}$ NNE of Yucca Mountain [Haimson et al., 1974; Smith et al., 1981; Ellis and Magner, 1980]. In order to determine the magnitudes and directions of the principal stresses at the proposed repository site, we performed a series

\footnotetext{
${ }^{1}$ Now at Department of Earth, Atmospheric, and Planetary Sciences, Massachusetts Institute of Technology, Cambridge.

${ }^{2}$ Now at Department of Geophysics, Stanford University, California.

This paper is not subject to U.S. copyright. Published in 1985 by the American Geophysical Union.

Paper number 4B5237.
}

of hydraulic fracturing stress measurements and acoustic borehole televiewer observations in two wells (USW G-1 and USW G-2).

\section{Location aNd Geologic Setting}

Yucca Mountain straddles the western boundary of the Nevada Test Site at approximate coordinates $36^{\circ} 50^{\prime} \mathrm{N}$, $116^{\circ} 28^{\prime} \mathrm{W}$ (Figure 1). It is bounded on three sides by alluvial areas of low relief: on the east by Jackass Flats, on the west by Crater Flat, and on the south by the Amargosa valley.

Yucca Mountain consists of a series of gently east tilted blocks of Miocene volcanic units. The Tiva Canyon member of the Paintbrush Tuff (pre-11 Ma [Marvin et al., 1970]) crops out over most of the surface. Stratigraphic units encountered below the Tiva Canyon member, in descending order, are Yucca Mountain member, Pah Canyon member, and Topopah Springs member of the Paintbrush Tuff; the tuffaceous beds of Calico Hills; the Prow Pass member, Bullfrog member, and Tram member of the Crater Flat Tuff; lava and flow breccia; and the Lithic Ridge Tuff. Minor bedded tuffs are locally present between each of these units.

Drilling, gravity, and seismic refraction data show that the Miocene volcanic units probably extend to at least $3000 \mathrm{~m}$ depth beneath most of Yucca Mountain [Snyder and Carr, 1984; Hoffman and Mooney, 1983]. However, a gravity high on the east side of Yucca Mountain is believed to correspond to a high in the prevolcanic surface. In this area, drill hole Ue25p-1 (see Figure 2) penetrates Silurian limestones and dolomites at $1400 \mathrm{~m}$ depth. These Paleozoic rocks are part of the Precambrian through upper Paleozoic clastic and carbonate sequence that crops out west of Crater Flat at Bare Mountain and east of Yucca Mountain in the Calico Hills and Striped Hills.

The structural style at Yucca Mountain is dominated by high-angle, NW to NE striking, west dipping normal faults which tilt strata to the east (Figure 2). Vertical offset on these west dipping faults is generally small except for along the 


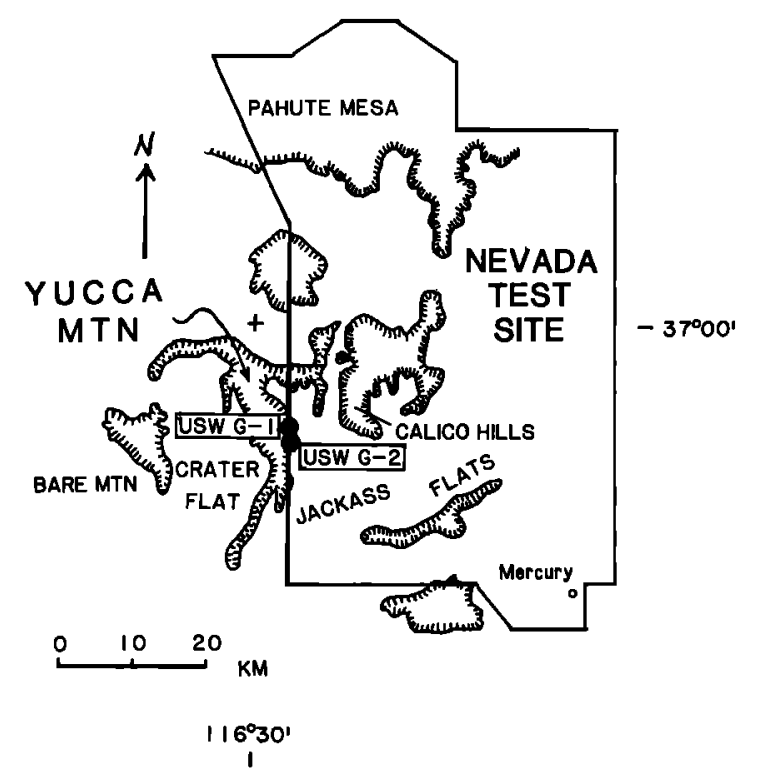

Fig. 1. Map of the Nevada Test Site and vicinity, showing locations of Yucca Mountain, Crater Flat, Pahute Mesa, Bare Mountain, and Jackass Flats.

bounding faults (e.g., the Paintbrush Canyon fault, with approximately $500 \mathrm{~m}$ vertical offset [Scott and Bonk, 1984]). The major normal movement on these faults occurred between 13 and $11.5 \mathrm{Ma}$; minor normal, strike-slip, or oblique movement may have continued into the Pliocene [Scott and Castellanos, 1984]. A second style of vertical NW striking faults, with subhorizontal slickensides and offsets of $100 \mathrm{~m}$ or less, is also present; motion on these faults is believed to predate $11.5 \mathrm{Ma}$ [Scott and Castellanos, 1984].

Crater Flat, a broad low region of alluvium and some Quaternary basalt eruptive centers, lies immediately west of Yucca Mountain. The volcanics of Crater Flat have been divided into three groups: 3.7-Ma basalt, consisting of feeder dikes, scoria deposits, and lava flows in the southeast portion of Crater Flat; a series of four 1.1-Ma Strombolian cinder cones along a slightly arcuate trend through the center of Crater Flat; and the 0.3-Ma Lathrop Wells cinder cone, immediately south of Yucca Mountain [Vaniman and Crowe, 1981]. Drill holes VH-1 and VH-2 in central Crater Flat pass through alluvium, Paleozoic slide blocks, and the Timber Mountain Tuff and encounter the same Miocene volcanic units seen in drill holes at Yucca Mountain [Carr, 1982, and written communication, 1984]. The dominant structural style of east tilted blocks bounded by west dipping high-angle faults extends from Yucca Mountain into eastern Crater Flat. Such faults have caused over $550 \mathrm{~m}$ of vertical separation in the Paintbrush Tuff between drill holes VH-1 and VH-2; they also produce minor displacement in the $3.7-\mathrm{Ma}$ volcanics [Carr, 1982].

USW G-1 is located in Drill Hole Wash, on the east side of Yucca Mountain, at coordinates $36^{\circ} 52^{\prime} 00^{\prime \prime} \mathrm{N}, 116^{\circ} 27^{\prime} 30^{\prime \prime} \mathrm{W}$, and a surface elevation of $1326 \mathrm{~m}$. USW G-2 is east of the crest of Yucca Mountain, at coordinates $36^{\circ} 53^{\prime} 22^{\prime \prime} \mathrm{N}$, $116^{\circ} 27^{\prime} 35^{\prime \prime} \mathrm{W}$. Its surface elevation is $1554 \mathrm{~m}$. Projections of the two holes along lines of maximum topographic relief (Figure 3) show that G-1 has significant drift toward the southwest into Yucca Mountain, whereas G-2 is essentially vertical. The holes penetrate units ranging from the Tiva Canyon member of the Paintbrush Tuff to some unnamed tuffs below the Lithic Ridge Tuff (see Spengler et al. [1981] and Maldonado and Koether [1983] for detailed stratigraphic descriptions).

\section{Hydraulic Fracturing Procedures}

The hydraulic fracturing stress measurement technique has been extensively described elsewhere [e.g., Haimson and Fairhurst, 1967; Hickman and Zoback, 1983]. Briefly, an interval of the drill hole is isolated between two rubber packers and pressurized until a tensile fracture forms in the borehole wall. The test interval is then "shut-in" (sealed off at the surface) and its pressure-time behavior is monitored. The pressure at which the fracture closes away from the well bore usually appears as an inflection in the pressure-time curve just after shut-in and is referred to as the instantaneous shut-in pressure, or ISIP. The surface valve is then opened to allow the pressure to bleed back to its pretest value. Normally, several more cycles of pressurization, shut-in, and bleeding back are conducted, until the ISIP reaches a stable value; this is interpreted as the normal stress on the fracture away from the well bore [Hickman and Zoback, 1983]. Theory [Hubbert and Willis, 1957] and numerous laboratory experiments [Haimson and Fairhurst, 1970; Haimson and Avasthi, 1975] show that the hydraulic fracture should propagate in a direction perpendicular to the direction of the least horizontal principal stress $S_{h}$, and thus the ISIP is taken to be equal to $S_{h}$.

The magnitude of the maximum horizontal principal stress $S_{H}$ can be determined if the rock is assumed to be homogeneous, isotropic, and linearly elastic, with one principal stress direction parallel to the borehole axis (i.e., vertical). Under these conditions the minimum tangential stress at the borehole wall occurs at the azimuth of the greatest horizontal principal stress $S_{H}$. The interval pressure required to create a hydraulic fracture at this azimuth depends on the tensile strength $T$ and the pore pressure $P_{p}$ and is called the breakdown pressure $P_{b}$ [Haimson and Fairhurst, 1967; after Hubbert and Willis, 1957]:

$$
P_{b}=3 S_{h}-S_{H}+T-P_{p}
$$

If an ISIP is not visible on the pressure-time curve (for example, because the high permeability of the interval obscures the inflection point), a step rate injection test [Earlougher, 1977] can help to constrain the normal stress on the fracture [see Hickman et al., 1985]. The stable pumping pressure for each of a series of decreasing flow rates is recorded. The resulting plot of flow rate as a function of pumping pressure will generally be linear in two regions, with a slope change reflecting the decrease in apparent permeability of the interval as the fracture closes.

Values of $S_{h}$ and $P_{b}$ determined from hydraulic fracturing test records can be used in equation (1) to solve for $S_{H}$ if the values of $T$ and $P_{p}$ are known. Because tensile strength $T$ is observed to depend on both the sample size and the type of tensile strength test performed [e.g., Hudson, 1971; Ratigan, 1983], $T$ as a function of sample size must be obtained through careful laboratory work and then extrapolated upward to the in situ borehole size. A more reliable value of $S_{H}$ can be obtained by using the fracture reopening pressure on the second cycle $\left(P_{b}\right.$ at $\left.T=0\right)$ to eliminate $T$ from equation (1) [Bredehoeft et al., 1976]:

$$
P_{b}(T=0)=3 S_{h}-S_{H}-P_{p}
$$

Equation (2) is only valid if the excess fluid pressure can be bled back from the interval after each cycle, so that the equi- 


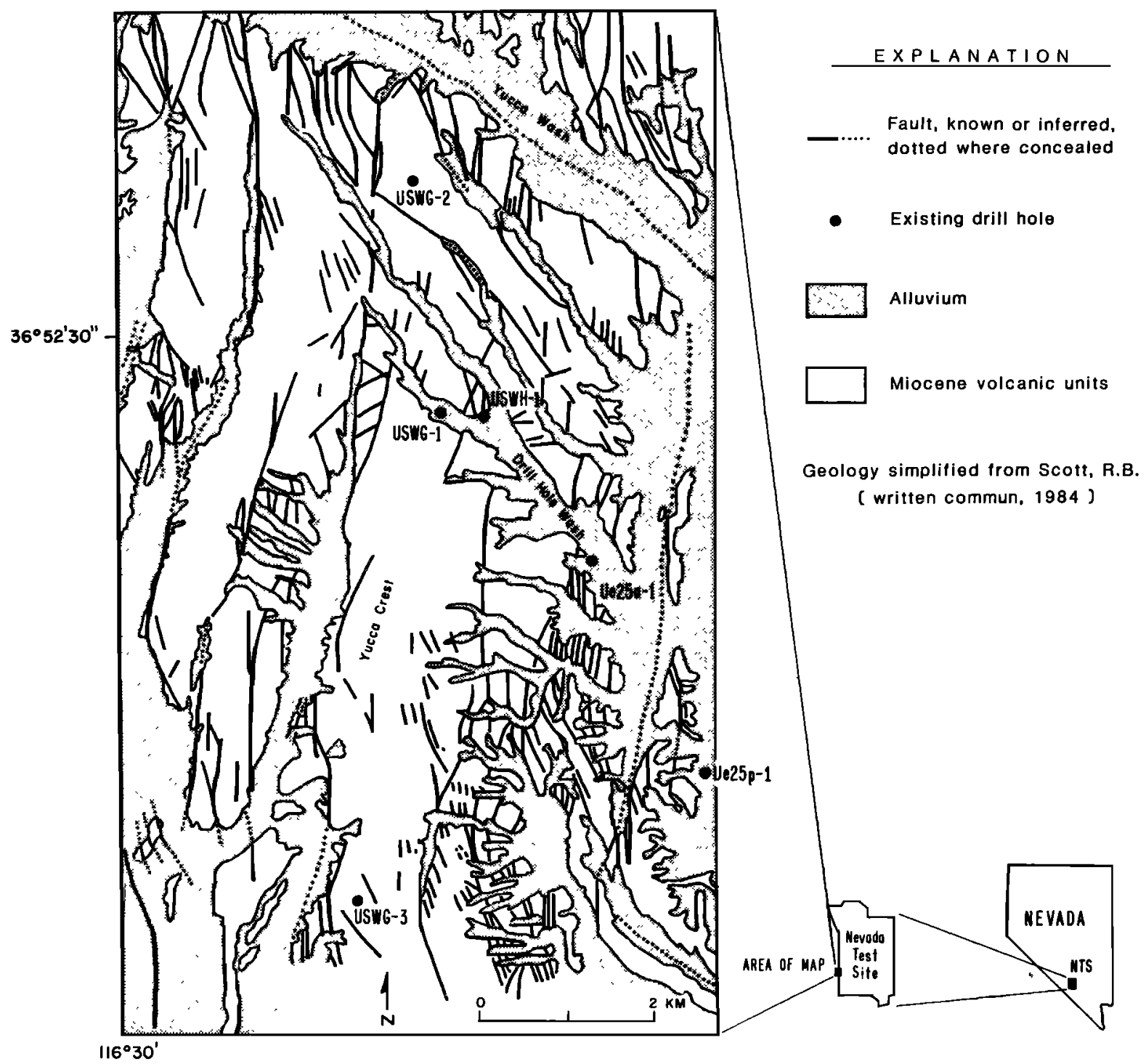

Fig. 2. Map of Yucca Mountain showing locations of drill holes discussed in text. White is outcrop of volcanics, and stippled pattern rèpresents alluvium.

librium pore pressure of the wall rock is not significantly disturbed. If the pressure in the interval cannot be bled back, the higher pressure in the interval may raise the pore pressure in the rock around the hole. Use of the equilibrium value of $P_{p}$ in equation (2) will then result in an erroneously high value of $S_{H}$. Under these circumstances, equation (2) can only be used to place an upper limit on the value of $S_{H}$ [Hickman and Zoback, 1983]. In this report we rely primarily on equation (2) for determination of $S_{H}$ values. The uncertainties in these $S_{H}$ values due to possible changes in $P_{p}$ are discussed along with the $S_{H}$ results below.

After successful hydraulic fracturing tests, impression packers are often used to obtain an oriented impression of the hydraulic fracture and determine the $S_{h}$ direction. In the tests in USW G-1 and USW G-2, no impression packers could be run due to time constraints. However, consistent and detailed information on the $S_{h}$ direction was obtained from other features in the televiewer log discussed below.

\section{Hydraulic Fracturing Results}

Eleven successful hydraulic fracturing tests were conducted in USW G-1 and USW G-2 (Table 1; Figures 4 and 5). The three shallowest tests in USW G-2 were in the unsaturated zone; all other tests were below the water table.

The unusually low water levels in these holes $1575 \mathrm{~m}$ in USW G-1 and $526 \mathrm{~m}$ in USW G-2) and the low horizontal stresses encountered in the tests mandated some modifications of typical testing procedure. The pressure in the interval often fell below surface hydrostatic pressure during the tests. In addition to the mechanical pressure recorder normally used downhole, a downhole electronic transducer transmitted pressure data to the surface through the wireline to provide realtime information on interval pressure. Because a wireline lubricator was used at the surface to seal the wellhead against the wireline, the rate of pressure decay decreases considerably whenever the pressure in the interval falls below surface hydrostatic pressure (e.g., Figure 5; see also Stock et al. [1984]). This change in slope is not necessarily an ISIP; it is caused by the change in compliance of the fluid-filled drill pipe and packer system as the water level drops below the top of the tubing string and a two-phase (water plus low-pressure water vapor) system is created. This transition from a fluid-filled (low compliance) to fluid- and vapor-filled (high compliance) system is reflected by a sudden increase in the apparent bore- 

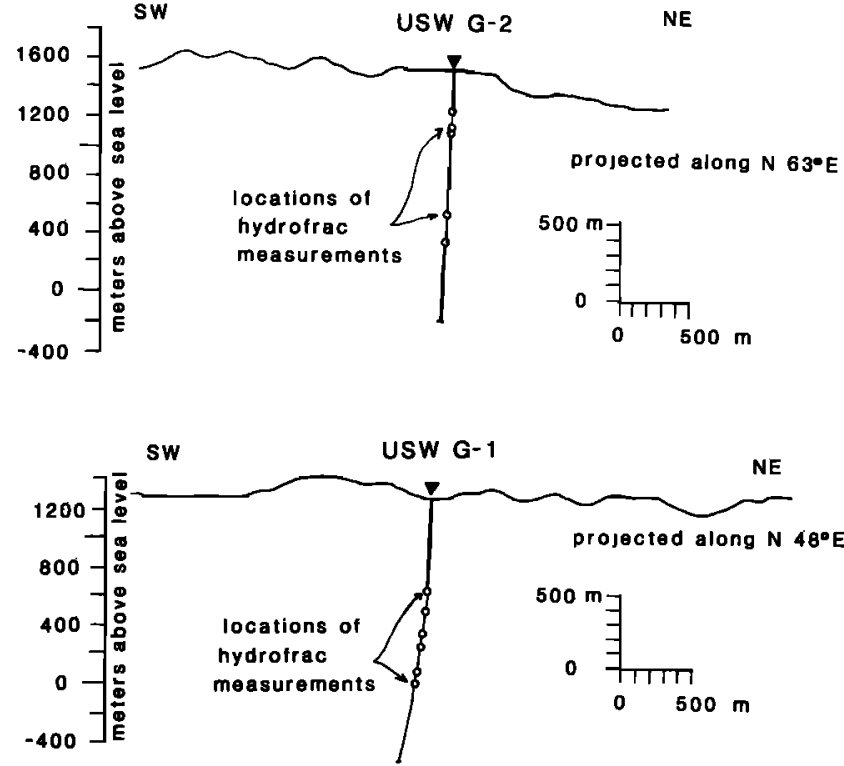

Fig. 3. Projections of holes USW G-1 and USW G-2 against topography, showing depths to hydrofrac measurements.

hole storage coefficient. (See Cooper et al. [1967] and Bredehoeft and Papadopulos [1980] for a discussion of borehole storage effects related to in situ permeability tests.)

The eight tests below the water table had clear breakdown pressures, and values of $S_{h}$ were determined from stable ISIP values or flat pumping pressures (Table 1). For three of the tests in USW G-2, step rate injection tests on the final pump- ing cycles were used to further constrain the ISIP values (Figure 5 and Stock et al. [1984]). In the three tests in the unsaturated zone (tests at 295, 418, and $432 \mathrm{~m}$, USW G-2, Figure 5) the breakdown pressures on the first cycle were the same as fracture reopening pressures on the later cycles, suggesting that preexisting fractures were being reopened rather than new hydrofractures being created. If the preexisting fractures were not perpendicular to $S_{h}$, the normal stress on the fracture (the ISIP) may exceed $S_{h}$. We therefore use the three ISIP values recorded in these tests as upper bounds on the $S_{k}$ value at these depths. Because no televiewer logs or fracture impressions could be obtained in the unsaturated zone, information on density and orientation of preexisting fractures is poor. However, as discussed below, most of the fractures in the zone below the water table in USW G-2 have normals within $30^{\circ}$ of the $S_{h}$ direction. If the fractures in the unsaturated zone have similar orientations, it is likely that the ISIP values determined from these tests are close to $S_{h}$.

Because of uncertainty over which values of tensile strength to use in equation (1), estimates of the maximum horizontal stress $S_{H}$ are obtained using equation (2). These $S_{H}$ values are poorly constrained because of the following uncertainties in $P_{p}$. In USW G-1 the circulation valve between the packers was opened using a weighted bar on the end of the wireline. This bar had to be brought back to the surface prior to sending the pressure gauge downhole and sealing off the wellhead so that testing could begin. This required a wait of approximately 1 hour between the time that the circulation valve between the packers was opened (allowing water pressure in the drill pipe to enter the test interval) and the time that pressurization of the interval to breakdown could begin.

TABLE 1. Summary of Stress Measurements, USW G-1 and USW G-2

\begin{tabular}{|c|c|c|c|c|c|c|c|}
\hline \multicolumn{5}{|c|}{ Hydraulic Fracturing Data } & \multicolumn{3}{|r|}{ Principal Stresses } \\
\hline $\begin{array}{c}\text { Depth, } \\
\text { m }\end{array}$ & $\begin{array}{l}\text { Breakdown } \\
\text { Pressure, } \\
\mathrm{MPa}\end{array}$ & $\begin{array}{l}\text { Shut-In } \\
\text { Pumping } \\
\text { Pressure, } \\
\text { MPa }\end{array}$ & $\begin{array}{l}\text { Hydrostatic } \\
\text { Pressure, } \\
\text { MPa }\end{array}$ & $\begin{array}{l}\text { Pore } \\
\text { Pressure, }{ }^{* \dagger} \dagger \\
\text { MPa }\end{array}$ & $\begin{array}{l}\text { Minimum } \\
\text { Horizontal } \\
\text { Stress, } \\
\text { MPa }\end{array}$ & $\begin{array}{l}\text { Vertical } \\
\text { Stress } \\
\text { MPa* }\end{array}$ & Comments \\
\hline \multicolumn{8}{|c|}{ USW G-I } \\
\hline 646 & 8.3 & $4.2 \pm 0.2$ & 6.2 & 0.7 & $4.2 \pm 0.2$ & 12.9 & $\begin{array}{l}\text { Minimum horizontal stress from flat } \\
\text { subhydrostatic pumping pressure } \\
\text { attained during second cycle. } S_{h} \\
\text { may thus be several bars too high } \\
\text { due to pressure gradient in fracture. }\end{array}$ \\
\hline 792 & 10.2 & $7.2 \pm 0.2$ & 7.9 & 2.2 & $7.2 \pm 0.2$ & 15.9 & Same as above. \\
\hline 945 & 13.2 & $9.0 \pm 0.2$ & 9.2 & 3.6 & $9.0 \pm 0.2$ & 19.2 & Same as above. \\
\hline 1038 & 13.5 & $10.6 \pm 0.2$ & 10.3 & 4.5 & $10.6 \pm 0.2$ & 21.4 & $\begin{array}{l}\text { Minimum horizontal stress from stable } \\
\text { instantaneous shut-in pressures } \\
\text { attained in final cycles. }\end{array}$ \\
\hline 1288 & 23.8 & $14.8 \pm 0.2$ & 12.8 & 7.0 & $14.8 \pm 0.2$ & 27.2 & Same as above. \\
\hline \multicolumn{8}{|c|}{ USW G-2 } \\
\hline 295 & 5.1 & $5.1 \pm 0.1$ & 2.9 & 0.0 & $5.1 \pm 0.1$ & 6.1 & $\begin{array}{l}\text { Reopening preexisting fracture of } \\
\text { unknown orientation: shut-in pumping } \\
\text { pressure is upper bound on } S_{k} \text {. }\end{array}$ \\
\hline 418 & 5.4 & $5.4 \pm 0.1$ & 4.1 & 0.0 & $5.4 \pm 0.1$ & 8.4 & Same as above. \\
\hline 432 & 5.5 & $5.5 \pm 0.1$ & 4.2 & 0.0 & $5.5 \pm 0.1$ & 8.7 & Same as above. \\
\hline 1026 & 16.3 & $11.1 \pm 0.2$ & 10.1 & 4.9 & $11.1 \pm 0.2$ & 20.8 & $\begin{array}{l}\text { Minimum horizontal stress from stable } \\
\text { pumping pressure on multiple cycles. }\end{array}$ \\
\hline 1209 & 18.2 & $12.0 \pm 0.2$ & 11.8 & 6.7 & $12.0 \pm 0.2$ & 25.5 & $\begin{array}{l}\text { Minimum horizontal stress from flat } \\
\text { pumping pressure attained on second } \\
\text { cycle. } S_{h} \text { thus may be several bars } \\
\text { too high due to pressure gradient } \\
\text { in fracture. }\end{array}$ \\
\hline
\end{tabular}

*Calculated for the appropriate density and depth.

$\dagger$ Based on water table at $576 \mathrm{~m}$ depth in USW G-1 and $526 \mathrm{~m}$ depth in USW G-2. 


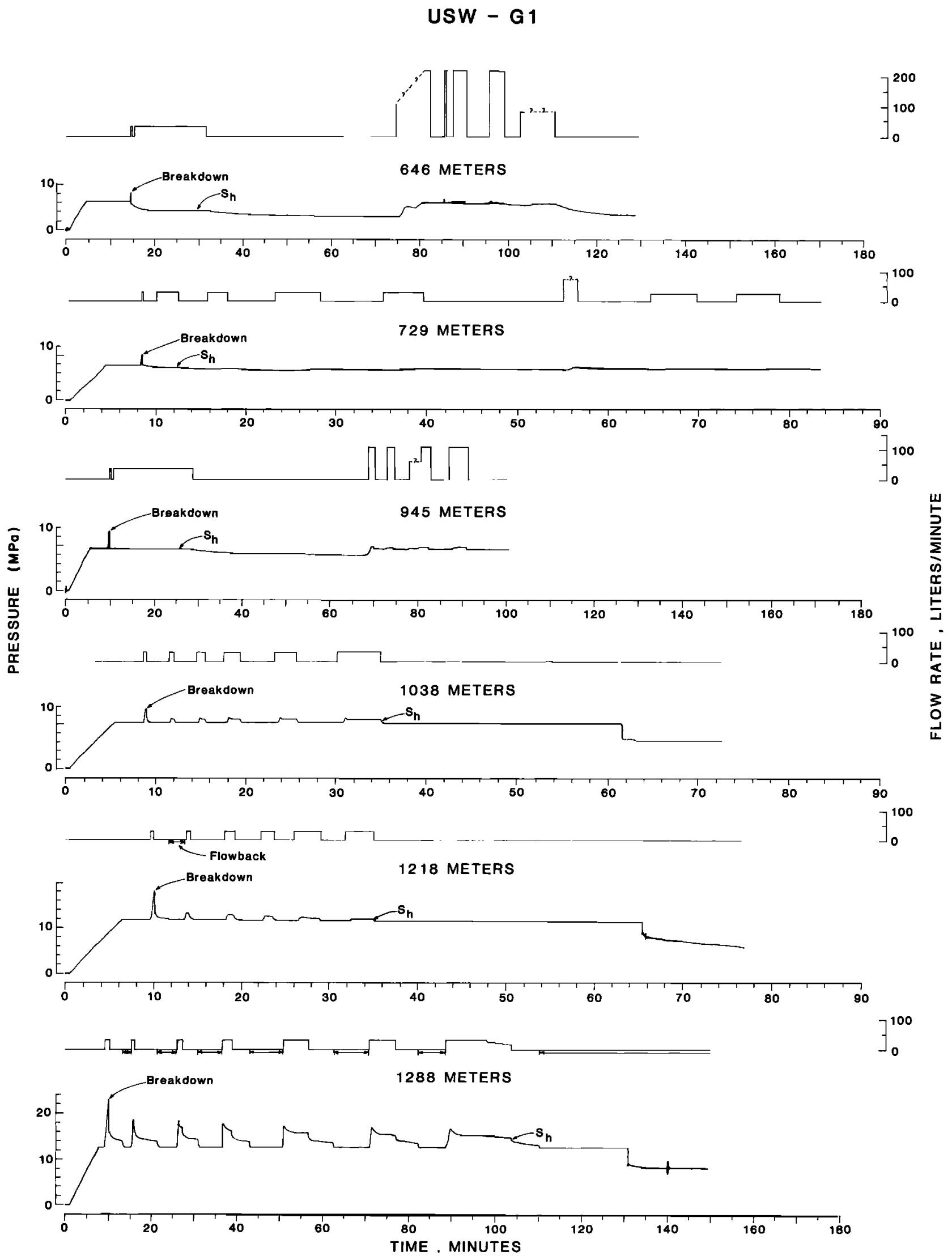

Fig. 4. Hydraulic fracturing test data from tests in USW G-1, showing downhole pressure and flow rate as a function of time. 


\section{USW G-2}
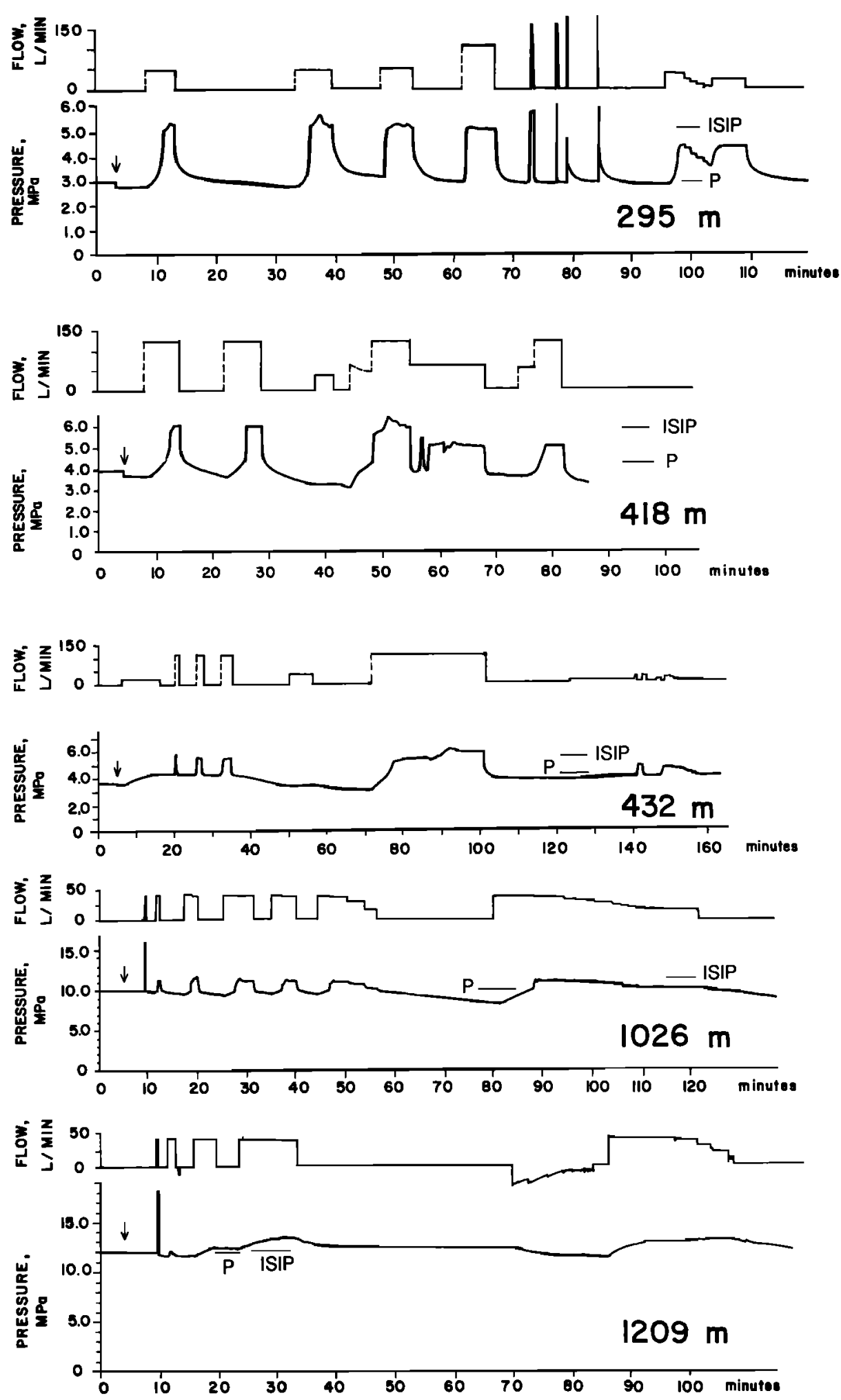

Fig. 5. Hydraulic fracturing test data from tests in USW G-2, showing downhole pressure and flow rate as a function of time. Arrows indicate time when circulation valve was opened and the interval was exposed to the pressure in the tubing string. The upper three tests were conducted above the water level in the hole, and the drop in pressure following the opening of the circulation valve results from water rushing in to replace the air in the test interval. ISIP, value of $S_{h}$ obtained from the test; $P$, surface hydrostatic pressure. Note the change in slope of the pressure decay curves, caused by the change in compliance of the drill pipe-packer system, when the pressure falls to the surface hydrostatic pressure $P$. 
During this time the test interval was exposed to surface hydrostatic pressure that was $5.7 \mathrm{MPa}$ above the water table hydrostatic pressure. However, because of the absence of preexisting fractures in the hydrofrac interval and the stability of the water level in the drill pipe as observed by us at the wellhead during this period, it is unlikely that this excess pressure significantly raised the pore pressure around the test interval prior to breakdown on the first cycle. After the first cycle the pressure could not be bled back to the water table hydrostatic pressure, so that the actual pore pressure during later cycles $\left(\boldsymbol{P}_{p}\right.$ in equation (2)) may have increased through flow of water through the walls of the newly created hydraulic fracture into the formation.

For the USW G-2 tests the weighted bar and downhole pressure gauges were combined as a single wireline assembly, and a wireline lubricator was used to seal off the wellhead, so that testing could begin almost immediately after knockdown. Thus the interval was only exposed to abnormally high fluid pressures for a few minutes before breakdown. The pore pressure at the beginning of the first cycle in the USW G-2 tests can be taken as equal to the water table hydrostatic pressure without reservation. As in the USW G-1 tests, the pressure could not be bled back to the water table hydrostatic pressure after the first cycle. Therefore in both USW G-1 and USW G-2 we use the water table hydrostatic pressure as a lower bound and the ground surface hydrostatic pressure as an upper bound on the value of $P_{p}$ in equation (2).

These bounding values of $P_{p}$ in equation (2) were used to obtain bounding values of $S_{H}$ for three of the tests: the two deepest tests in USW G-2 and the deepest test in USW G-1, all of which showed clear fracture reopening pressures significantly different from the initial breakdown pressure. Other
TABLE 2. Constraints on $S_{H}$ From Hydraulic Fracturing Measurements, USW G-1 and USW G-2

\begin{tabular}{|c|c|c|c|}
\hline & \multicolumn{2}{|c|}{ USW G-2* } & USW G-1† \\
\hline Depth, m & 1026 & 1209 & 1288 \\
\hline Breakdown pressure, MPa & 16.3 & 18.2 & 23.8 \\
\hline Shut-in pressure, MPa & $11.1 \pm 0.2$ & $12.0 \pm 0.2$ & $\cdots$ \\
\hline $\begin{array}{c}\text { Surface Hydrostatic } \\
\text { pressure, } \mathbf{M P a}\end{array}$ & 10.1 & 11.8 & 12.8 \\
\hline $\begin{array}{l}\text { Water Table Hydrostatic } \\
\text { pressure, } \mathbf{M P a}\end{array}$ & 4.9 & 6.7 & 7.7 \\
\hline $\mathrm{S}_{h}, \mathrm{MPa}$ & $11.1 \pm 0.2$ & $12.0 \pm 0.2$ & $14.8 \pm 0.2$ \\
\hline $\begin{array}{l}S_{H} \text { from equation (2), } \mathrm{MPa} \\
\text { If } P_{p}=\text { water table } \\
\text { hydrostat }\end{array}$ & $16.8 \pm 0.4$ & $17.3 \pm 0.4$ & 17.9 \\
\hline $\begin{array}{l}\text { If } P_{p}=\text { surface } \\
\text { hydrostatic pressure }\end{array}$ & $11.6 \pm 0.4$ & $12.2 \pm 0.4$ & 12.8 \\
\hline $\begin{array}{r}\text { Fracture reopening } \\
\text { pressure, } \mathbf{M P a}\end{array}$ & 11.6 & 12.0 & 18.8 \\
\hline$S_{v}, \mathrm{MPa}$ & 20.8 & 25.5 & 27.2 \\
\hline
\end{tabular}

-Values of $S_{H}$ derived assuming $P_{p}=$ water table hydrostat are likely to be more reasonable since they imply more reasonable rock tensile strength if the resultant $S_{H}$ value is used in equation (1).

†Note that since $S_{h}<S_{h}, P_{p}=$ surface hydrostat is too high an upper limit for $\boldsymbol{P}_{p}$ in equation (2).

tests were not used because they either showed fracture reopening pressures that were not significantly different from the initial breakdown pressure (shallower tests in USW G-2) or because the fracture reopening pressures were subhydrostatic and could not be accurately determined (shallower tests in USW G-1). The $S_{H}$ values obtained in all three cases are greater than $S_{h}$ and less than $S_{v}$ (Table 2), so that $S_{H}$ is the
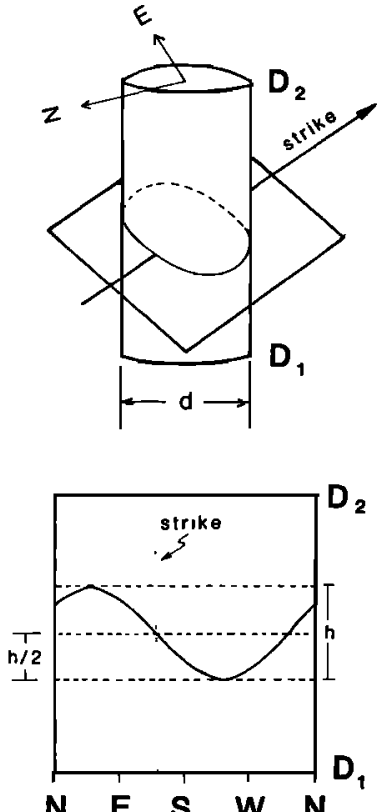

BOREHOLE TELEVIEWER LOG

Strike: orientation of midpoint between peak and trough

Dip $\tan ^{-1}(h / d)$
USW G- 2

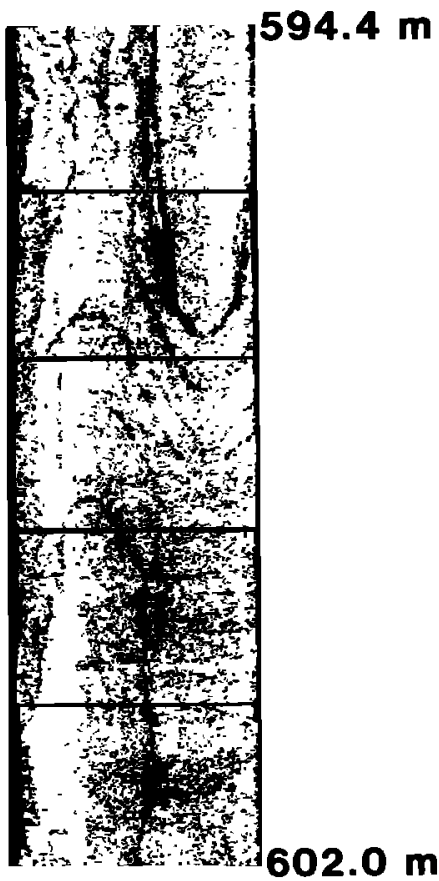

steeply dipping

subparallel

fractures
USW G- 2

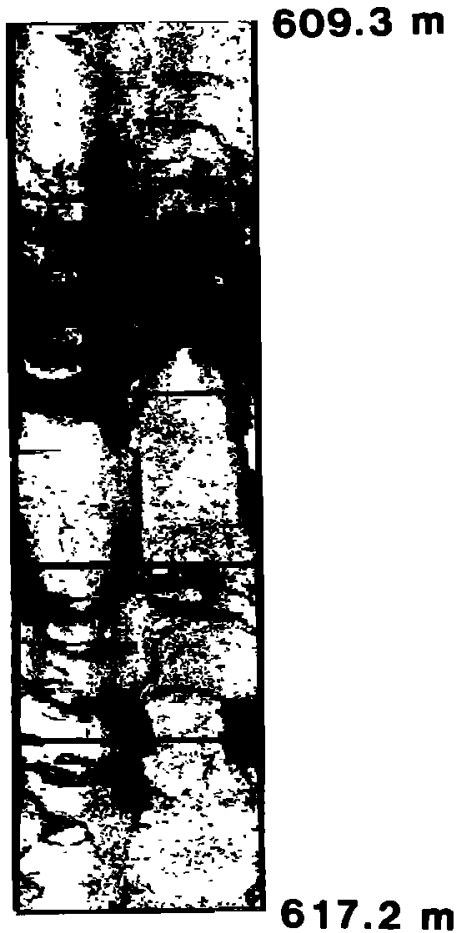

shallowly dipping fractures

Fig. 6. Televiewer fracture with sketch of how strike and dip are measured. 


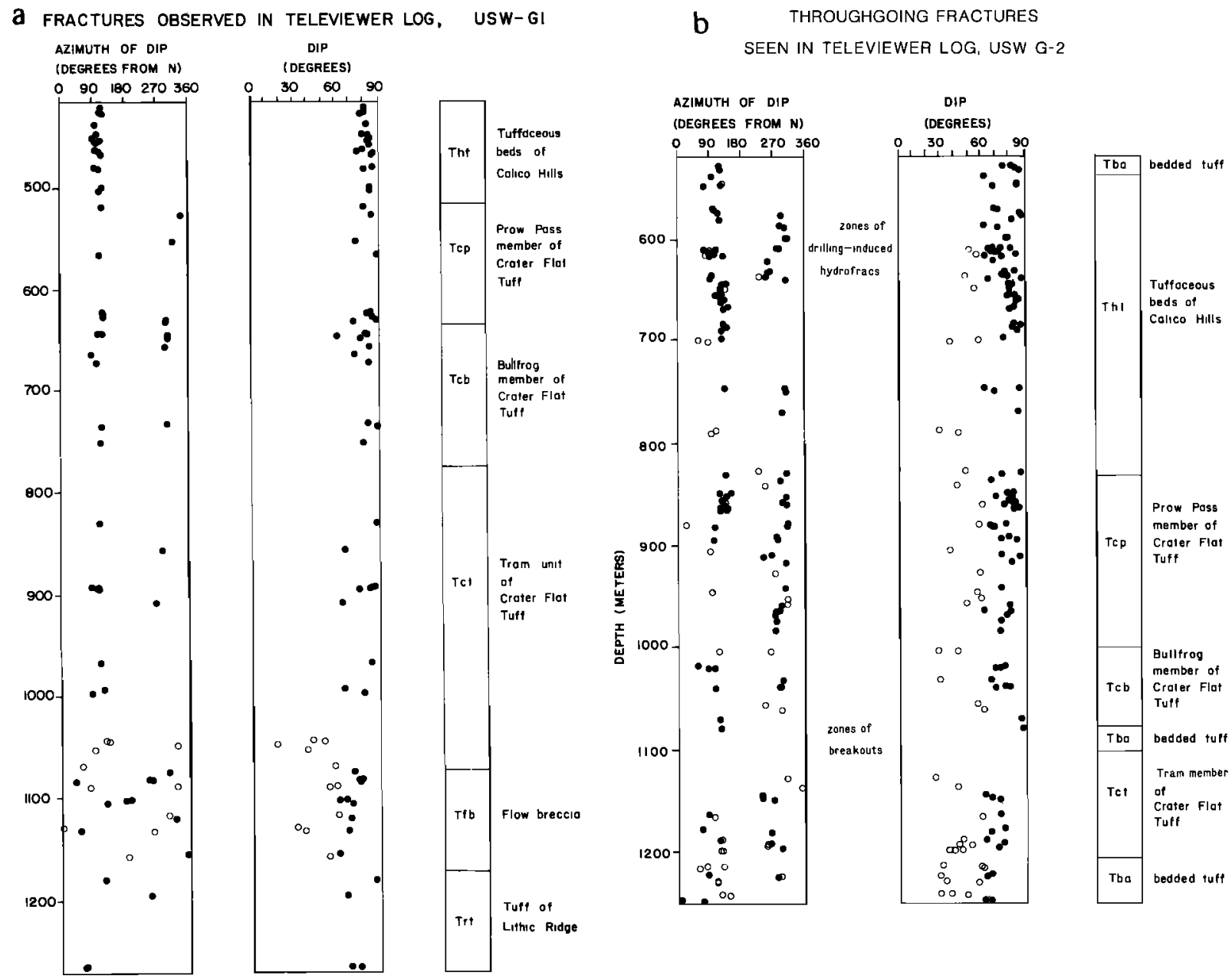

Fig. 7. Plot of azimuth and angle of dip as a function of depth for the throughgoing fractures observed in the televiewer logs of (a) USW G-1 and (b) USW G-2. The open circles represent fractures which dip less than $60^{\circ}$; solid circles represent fractures which dip $60^{\circ}$ or more.

intermediate principal stress, clearly indicating a normal faulting stress regime.

Note that the use of equation (2) assuming equilibration of $P_{p}$ to the surface hydrostatic pressure (our upper bound on $P_{p}$ ) would give $S_{H}$ values very close to $S_{h}$ values, implying a pure normal faulting stress regime. With $S_{h}$ close to $S_{H}$ in magnitude, well bore spalling would be unlikely to occur, and if it did so, it might show quite variable and discontinuous changes in orientation with depth [see Zoback et al., 1985]. The presence of continuous well bore spalling along consistent azimuths in both USW G-1 and USW G-2 implies that a considerable difference in the magnitudes of $S_{h}$ and $S_{H}$ is maintained at depth, so that the closer values of $S_{h}$ and $S_{H}$ corresponding to our upper bound on $P_{p}$ are probably unlikely.

The vertical stress $S_{v}$ is normally calculated as the saturated weight of the overlying rocks. Because the densities of these volcanic units vary greatly according to lithology, compaction, and degree of welding [e.g., Anderson, 1981], a constant $S_{v}$ gradient could not be assumed. Values of $S_{v}$ were based on integration of data from commercial borehole compensated density logs, where available, for both USW G-1 and USW G-2 (see tables of Healy et al. [1984] and Stock et al. [1984]).

Fig. 8. (opposite) Lower hemisphere, equal-area projections of poles to the throughgoing fractures observed in the televiewer logs of (a) USW G-1 and (b) USW G-2. a NEVADA TEST SITE USW G-1

Poles to trectures seen in televiewer log

Lower hemisphere, equal area projecllon
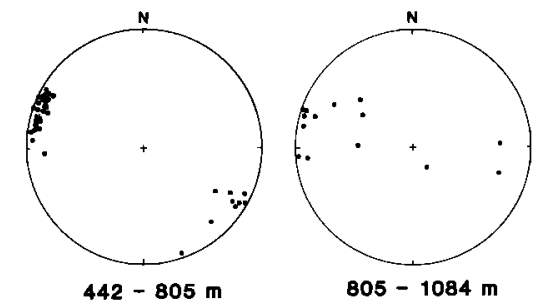

$805-1084 \mathrm{~m}$

TRAM MEMEER

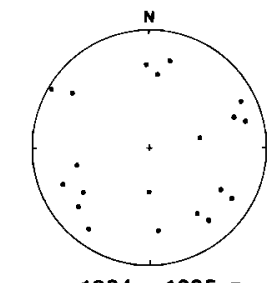

1084 - $1295 m$

FLOW BAECCIA

ATHO RIDGE TUFF

PHOW PASS MEMBEA

BULLFROO MEMBER

NEVADA TEST SITE USW G-2

Poles to tractures seen in televlewer log

Lower hemisphere, equal area projection

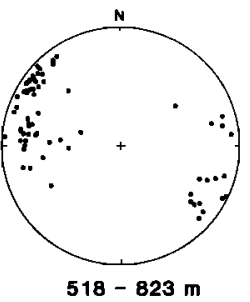

TUFFACEDUS BEDS OF

CALICO HILLS
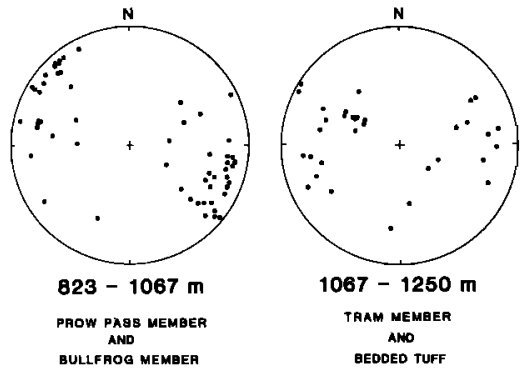


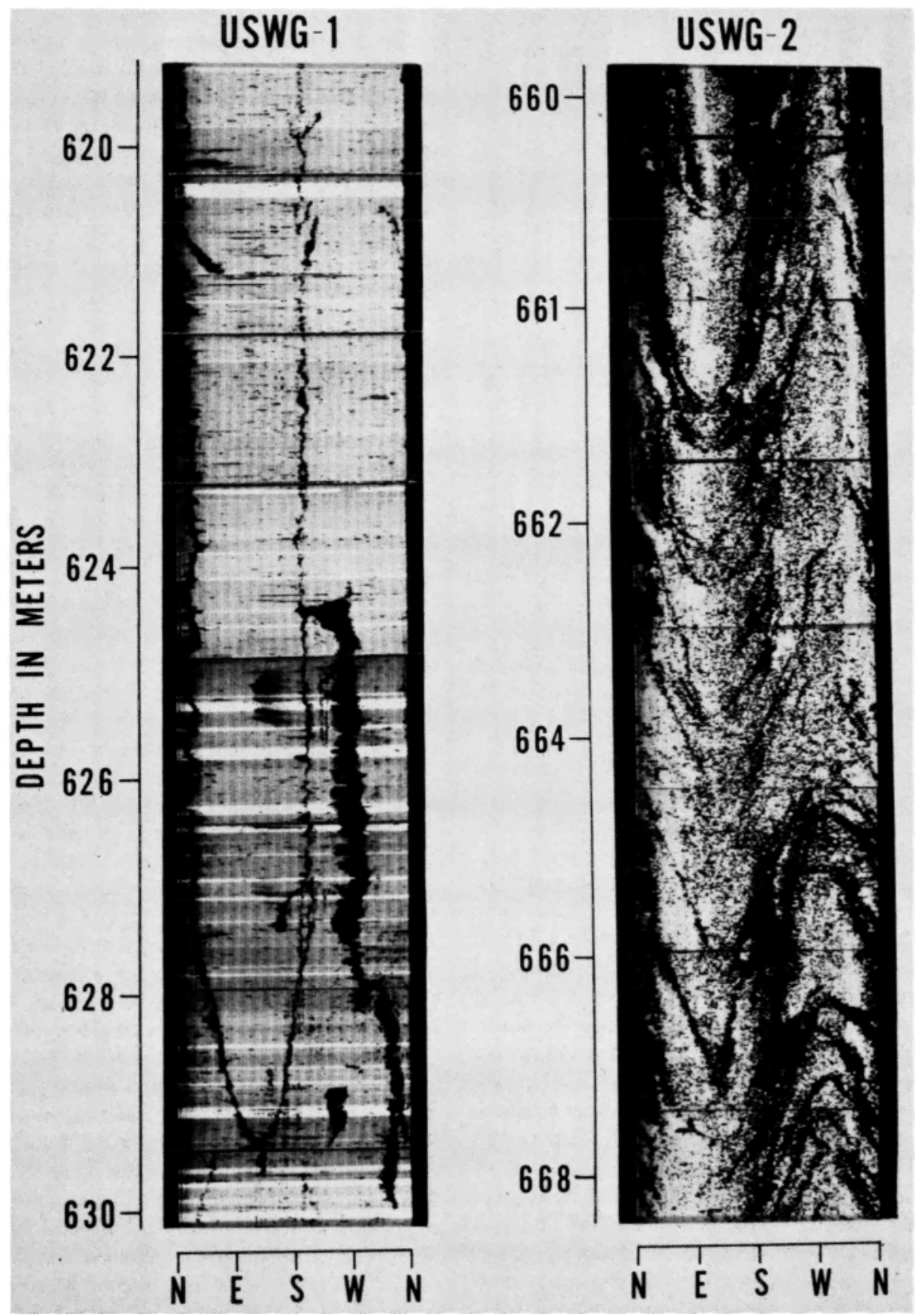

Fig. 9. Examples of drilling-induced hydrofractures, USW G-1 (10.4 cm drilled diameter) and USW G-2 (22.2 cm drilled diameter).

No borehole gravity studies were made in USW G-2, but borehole gravity measurements from USWW G-1 agree very closely with the compensated density log [Snyder and Carr, 1984; D. Muller, personal communication, 1983]. This suggests that the densities obtained by compensated density logs are representative of a large region around the borehole and can be considered a reliable source for estimating $S_{v}$.

\section{Method}

\section{BOREHOLE TELEVIEWER}

The borehole televiewer is a logging tool used to map the smoothness of the borehole wall. It is useful in identifying natural and drilling-induced fractures, borehole spalling (breakouts), and, in some cases, bedding. Principles of its operation and use have been described by Zemanek et al. [1969, 1970] and are briefly reviewed here.

The televiewer consists of a $2-\mathrm{MHz}$ acoustic transducer which pulses 1800 times/s and rotates 3 times/s. It is pulled up the hole at a constant speed of $2.5 \mathrm{~cm} / \mathrm{s}$. The returned signal is plotted on a three-axis oscilloscope, with depth on the vertical axis, azimuth on the horizontal axis, and brightness as a function of the amplitude of the reflected pulse. A flux gate magnetometer triggers on magnetic north and emits a pulse during each revolution. Photographs of the oscilloscope display, 


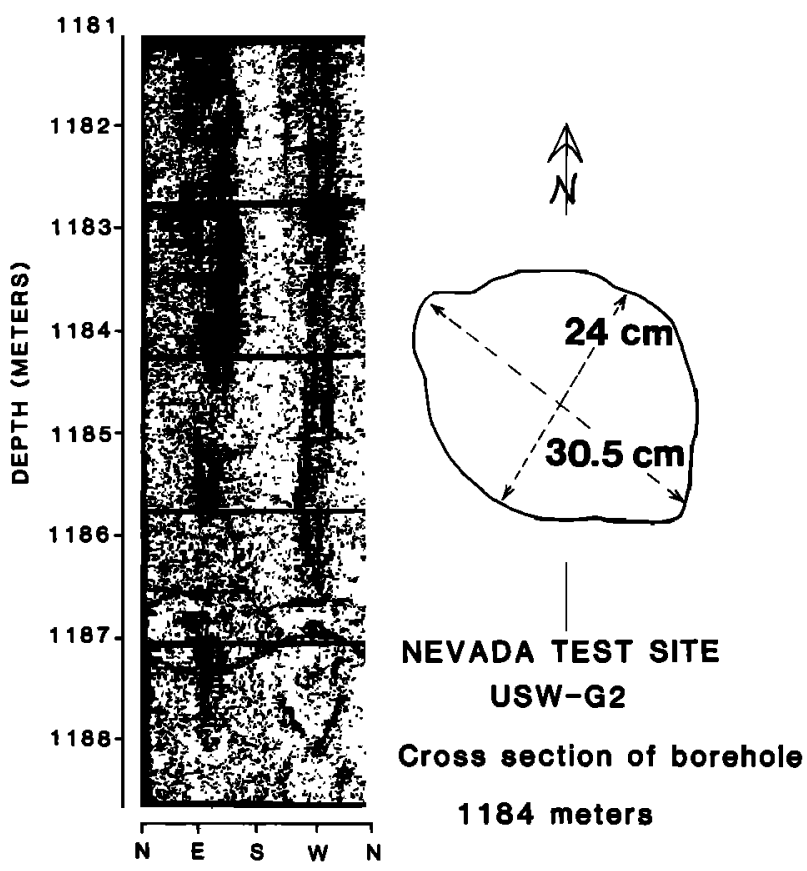

Fig. 10. Sample breakout cross section, obtained by reprocessing the returned signal from the acoustic televiewer. This part of the borehole was drilled to $22.2-\mathrm{cm}$ diameter.

taken at regular intervals, are used to form a continuous log of the hole.

On the televiewer $\log$, smooth regions of the borehole wall will appear as bright areas, and regions of roughness (e.g., fractures, breakouts) or regions that are obliquely angled with respect to the emitted pulse will show up as dark areas. For example, a planar fracture inclined to the borehole axis will appear as a sinusoidal dark band on the log. The strike and dip of such a fracture can be determined from measurement of the amplitude and phase of its trace on the televiewer photo (Figure 6). The returning signal is also recorded on magnetic tape and can be reprocessed in a travel time mode to create cross-sectional views of the hole, on which borehole spalling, tool eccentricity, and the depth of borehole wall features can be measured.

For a constant logging speed, vertical distortion of features in the $\log$ varies with borehole diameter. Since USW G-1 was about half the size of USW G-2 (10.4-cm bit diameter versus $22.2-\mathrm{cm}$ bit diameter), there is greater horizontal exaggeration on the USW G-1 log. This exaggeration improves the resolution of steeply dipping features but makes the identification of shallowly dipping features more difficult. In general, for the logging speed used, resolution is limited to features dipping more than $30^{\circ}$.

\section{Results}

Televiewer logs were obtained in USW G-1 from 1318 to $450 \mathrm{~m}$ and in USW G-2 from 1250 to $526 \mathrm{~m}$. Both holes were blocked at the bottom of the logged interval; the top of the logged interval is the fluid level in the hole. The complete logs, obtained prior to hydraulic fracturing, have been reproduced by Healy et al. [1984] and Stock et al. [1984]. Logs were run after testing to check for changes in the test intervals and for hydraulic fractures, but no differences between these logs and the earlier logs were observed. Although the entire logs are too long to be presented here, some of the more interesting features are discussed.
Throughgoing fractures (defined as fractures for which both updip and downdip intersections with the hole are visible on the televiewer log) are present at all depths. The majority of these dip at angles greater than $60^{\circ}$. Plots of the dip direction as a function of depth for fractures in USW G-1 (Figure 7a) show that in the upper part of USW G-1, these fractures strike slightly east of north and usually dip steeply to the ESE. Below about $1050 \mathrm{~m}$ they have more scattered orientations, and some quite shallow dips are observed. Many more fractures are seen in the USW G-2 televiewer log (Figure $7 b$ ) than in the USW G-1 log. In the upper $500 \mathrm{~m}$ of the USW G-2 log the fractures show a preferred orientation of NNE strikes and high-angle dips (greater than $60^{\circ}$ ) to either ESE or WNW. A few fractures with dips less than $60^{\circ}$ occur throughout the log. The scatter in dip direction increases slightly with depth for both low-angle and high-angle fractures.

Stereographic projections of poles to the throughgoing fractures (Figure 8) show that in USW G-2 the fractures clearly become less steep with depth. This is also the case for the fractures seen in USW G-1, although it is a much more abrupt change.

Most of these fractures cannot be easily correlated with fractures in the core because the core was not oriented with respect to north. Although larger fault zones seen in the televiewer logs can be correlated with similar features in the core, there are many more fractures in the core than in the televiewer log. Some of these may be due to the coring process; many are probably preexisting fractures that were too small to be resolved by the televiewer. We infer that most of the throughgoing fractures seen in the televiewer log were present before drilling; the NW to NE strikes are consistent with surface observations of NW to NE trending faults on Yucca Mountain (Figure 2).

Very high angle, nonthroughgoing fractures are also prominent in the upper part of the televiewer logs (Figure 9). In USW G-1 these occur between 520 and $760 \mathrm{~m}$ depth, as long single fractures with strikes between $\mathrm{N} 15^{\circ} \mathrm{E}$ and $\mathrm{N} 35^{\circ} \mathrm{E}$. In USW G-2 they occur between 526 and $678 \mathrm{~m}$ depth, as en echelon subparallel fractures merging into one another along a strike of $\mathrm{N} 25^{\circ} \mathrm{E}$ to $\mathrm{N} 30^{\circ} \mathrm{E}$. Because some of the corresponding sections of core are unfractured, these fractures were probably created after coring. We believe that these are hydrofractures induced by the drilling process, which are oriented perpendicularly to the $S_{h}$ direction (implying that $S_{h}=$ $\mathrm{N} 65^{\circ} \mathrm{W}$ in USW G-1 and $\mathrm{N} 60^{\circ} \mathrm{W}$ in USW G-2). The stress conditions required to form these fractures are discussed later.

Throughout large sections of the USW G-1 televiewer log and at depth in the USW G-2 televiewer log, vertical black bands occur in pairs centered at azimuths approximately $180^{\circ}$ apart. There are two types of black bands: very regular, continuous black bands with fuzzy, gradational edges and more irregular bands, often discontinuous, with sharp, jagged edges. These were examined by reprocessing the recorded signal in travel time mode to produce a horizontal cross section of the hole [see Zoback et al., 1985]. The travel time cross sections of these bands demonstrate that the regular, continuous bands are due to the tool being off center in the hole. These dark bands are more prominent in the USW G-1 televiewer log because USW G-1 had a drift of up to $12^{\circ}$ toward the southwest (Figure 3). USW G-2 had a maximum drift less than $5^{\circ}$, so the tool was usually well centered and these regular black bands were not observed.

By contrast, the jagged, irregular black bands were found to correspond to preferentially enlarged (spalled) regions of the 


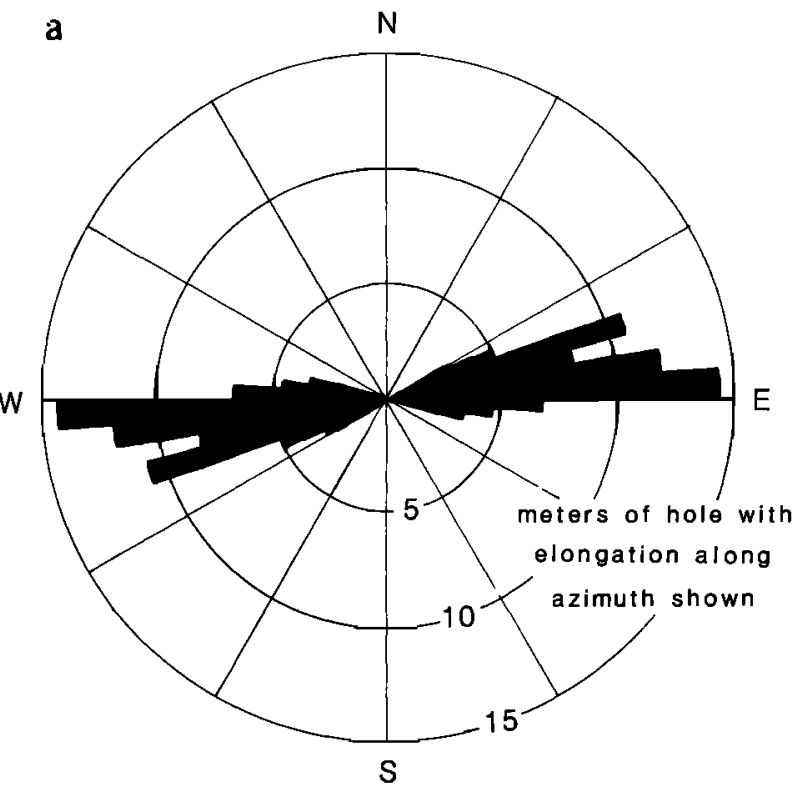

AZIMUTHS OF BREAKOUTS, NTS USW G-1

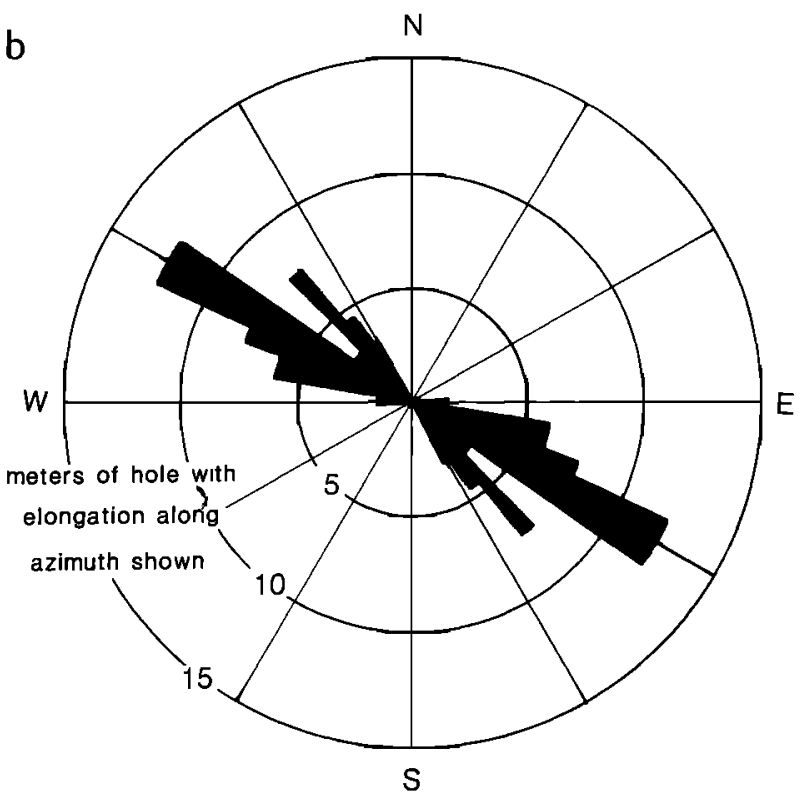

AZIMUTHS OF BREAKOUTS, NTS USW G-2

1113 - 1202 m DEPTH

1075 - 1218 M DEPTH

Fig. 11. Rose diagrams of the observed orientations of breakouts, averaged $(a)$ over each 0.3-m interval in USW G-1 and (b) over each $1.5-\mathrm{m}$ interval in USW G-2.

borehole (Figure 10). Their cross-sectional shapes varied from pointed or triangular to elliptical. Such regions of preferential spalling, or borehole breakouts, have also been identified on dipmeter logs from wells in Alberta, the Texas Gulf Coast, and Colorado [e.g., Bell and Gough, 1983]. Breakouts are believed to represent shear failure of the borehole wall in the region of high concentrated compressive stresses, centered on the azimuth of $S_{h}$ [Bell and Gough, 1979; Gough and Bell, 1981, 1982; Zoback et al., 1985]. Comparison of the direction of borehole elongation obtained from a borehole televiewer log with the azimuth of $S_{h}$ determined from hydraulic fracturing tests in the same well in central New York state [Hickman et al., 1985] as well as the agreement between the azimuth of $S_{h}$ as inferred from breakouts and that inferred from other field indicators within a given stress province [Zoback and Zoback, 1980; R. Plumb, manuscript in preparation, 1985] confirm this hypothesis. In addition, laboratory studies of breakout development by Mastin [1984] indicate that breakouts do occur centered at the azimuth of $S_{h}$ due to a combination of shear and tensile failure of the borehole wall.

In USW G-1, breakouts were continuously present from 1113 to $1202 \mathrm{~m}$ depth, with an average azimuth of $\mathrm{S} 80^{\circ} \mathrm{W}$ (Figure 11a). In USW G-2, breakouts were present at depths of 1053-1056, 1074, and 1084-1219 m, with an average azimuth of $\mathrm{N} 60^{\circ} \mathrm{W}$ (Figure $11 \mathrm{~b}$ ). The center azimuths of the breakouts thus suggest a $N 60^{\circ}-65^{\circ} \mathrm{W}$ orientation for $S_{h}$ in USW G-2, in good agreement with the $S_{h}$ direction indicated by the orientation of the drilling-induced hydrofractures in the upper parts of both USW G-1 and USW G-2. This direction is also in good agreement with that obtained from observations of borehole breakouts and drilling-induced hydraulic fractures in two other holes at Yucca Mountain, in the volcanics and underlying carbonate rocks [Stock and Healy, 1984]. The center azimuth of the USW G-1 breakouts implies an $S_{h}$ direction of $580^{\circ} \mathrm{W}$, a $35^{\circ}-40^{\circ}$ difference from the other directional indicators. Although deviation of the borehole from the vertical has been shown to have a significant effect on the orientation of stress-induced features such as hydraulic fractures [Richardson, 1983], calculations using the observed Yucca Mountain stress field $\left(S_{1}=\right.$ vertical, $S_{2}=\mathrm{N} 25^{\circ} \mathrm{E}, S_{3}=$ $\mathrm{N} 65^{\circ} \mathrm{W}$, and $\left.0.25 \leq\left(S_{2}-S_{3}\right) /\left(S_{1}-S_{3}\right) \leq 0.5\right)$ show that the hole deviation at this depth cannot completely account for the rotation of breakout azimuths. Deviation can explain this rotation if the greatest principal stress direction is more than $10^{\circ}$ from vertical, or if $S_{h}$ and $S_{H}$ are closer in magnitude than seen elsewhere at Yucca Mountain (Table 2 and Stock and Healy [1984]). Because the anomalously oriented breakouts occur in a fractured zone of flow breccia, such a local perturbation in the magnitude and/or direction of the principal stresses seems a likely possiblity.

\section{Discussion of Stress Measurements}

\section{Stability of Preexisting Faults}

A preexisting fault will slip if the shear stress $\tau$ applied to the fault surface reaches a value equal to $\left(s_{n}-P_{p}\right) \mu$ (the effective normal stress multiplied by the coefficient of friction, $\mu$ ). Under the stresses observed in the saturated zone of Yucca Mountain $\left(S_{v}>S_{H}>S_{h}\right.$, with $S_{h}$ oriented $\left.N 65^{\circ} \mathrm{W}\right)$ the plane with the highest ratio of shear to effective normal stress (the most favorable plane for slip) would strike parallel to $S_{H}$ $\left(\mathrm{N} 25^{\circ} \mathrm{E}\right)$ and $\operatorname{dip}$ either east or west at an angle $\theta$ related to the coefficient of friction $\mu$ by $2 \theta=\left(\tan ^{-1} \mu+90^{\circ}\right)$. For typical values of $\mu$ (between 0.6 and 1.0 [Byerlee, 1978]), such planes dip between $60^{\circ}$ and $67^{\circ}$. There are mapped faults at Yucca Mountain of approximately this orientation (Figure 2 and Scott and Bonk [1984]), and fractures of this orientation are also seen in the televiewer logs, as discussed above. Laboratory compressive strength tests of the Yucca Mountain tuffs (summarized by Price [1983]) indicate that in the ob- 

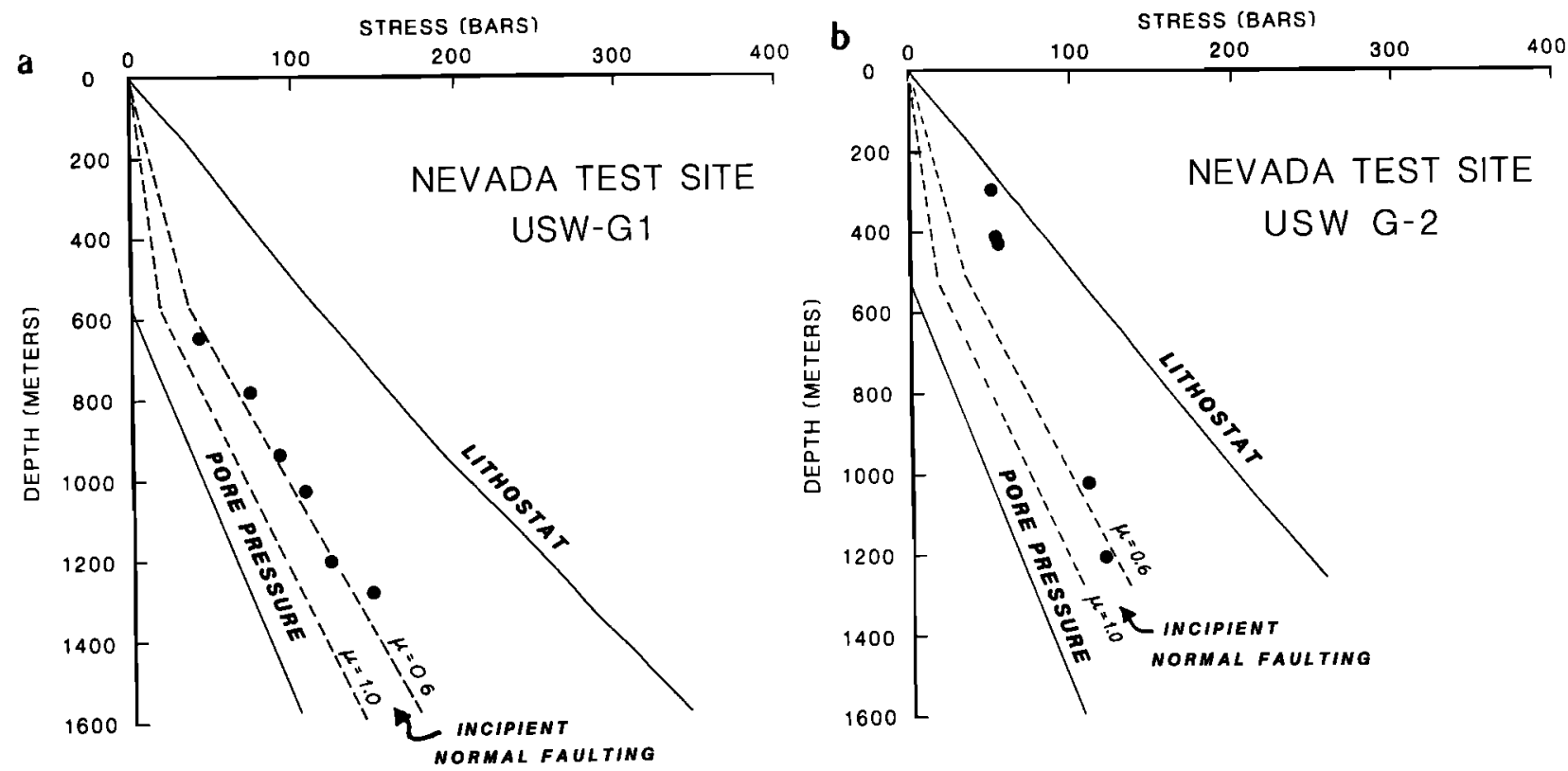

Fig. 12. Least horizontal principal stress values for $(a)$ USW G-1 and (b) USW G-2 plotted against depth. Lithostatic pressure $S_{v}$ and pore pressure (based on depth to water level in hole) are also shown. Stress values falling to the left of the dashed lines correspond to those for which slip might be expected to occur on preexisting favorably oriented normal faults, for reasonable values of the coefficient of friction, $\mu(0.6$ to 1.0$)$. Note that the upper three measurements in USW G-2 are upper limits on the value of $S_{h}$ (see text for discussion).

served stress regime, slip would occur preferentially on these faults rather than through the shear failure of intact rock.

For a favorably oriented fault plane, the expression $\tau=\mu\left(s_{n}\right.$ $-P_{p}$ ) can be rewritten in terms of the principal stresses as

$$
\frac{S_{1}-P_{p}}{S_{3}-P_{p}}=\left[\mu+\left(\mu^{2}+1\right)^{1 / 2}\right]^{2}
$$

[e.g., McGarr et al., 1982; Zoback and Hickman, 1982; Zoback and Healy, 1984]. In a normal faulting environment, such as the saturated zone of Yucca Mountain, $S_{1}=S_{v}$ and $S_{3}=S_{h}$; $S_{v}$ and $P_{p}$ are well constrained as a function of depth. Therefore, if $\mu$ is known, the condition for slip on a favorably oriented fault at a given depth can be defined in terms of a critical value of $S_{h}$. If $S_{h}$ exceeds this value, no slip will take place on any faults, but if $S_{h}$ is equal to or less than this value, slip will occur on favorably oriented preexisting faults.

Byerlee [1978] demonstrated that almost all rocks have laboratory coefficients of friction between 0.6 and 1.0. We therefore use these two bounding values of $\mu$ to compute critical values for $S_{h}$ as a function of depth for our measurements in the saturated zone (Figure 12). Measured $S_{h}$ values are close to those for which slip might take place on favorably oriented preexisting faults, if $\mu=0.6$. Slip should not occur if $\mu=1.0$. Laboratory coefficients of friction for samples of the Topopah Springs and Bullfrog member range from 0.7 to 0.9 [Morrow and Byerlee, 1984]. A value of 0.59 has been reported for the Prow Pass member [Olsson and Jones, 1980]. These values suggest that in at least part of the tuff section at Yucca Mountain, favorably oriented preexisting faults might slip under the current stress conditions.

\section{Formation of Drilling-Induced Hydrofractures}

Preexisting cracks of fairly large size are likely to have been present in USW G-1 and USW G-2, since much of the core contains lithophysal cavities, pumice fragments, lithics, and phenocrysts exceeding $1 \mathrm{~cm}$ in size. It therefore seems quite plausible that propagation of preexisting flaws occurred during drilling, as the hole was filled with fluid and downhole pumping pressure was applied. Such fractures would continue to propagate away from the borehole if the fluid pressure in them exceeded $S_{h}$. Pressures during drilling may have easily exceeded $S_{h}$ throughout much of USW G-1 and possibly also USW G-2 (Figure 13). We believe that this is the origin of the long, planar fractures which are prominent in both the USW G-1 and USW G-2 televiewer logs (as described above in televiewer results). The complete loss of circulation fluid experienced during drilling of these two holes can be explained by the fluid going into the drilling-induced fractures.

\section{Relationship of Yucca Mountain Stresses To THE Regional STRess Field}

The Nevada Test Site falls at the eastern edge of the stress transition zone defined by Zoback and Zoback [1980] between WNW-ESE extension characteristic of the Basin and Range province and the strike-slip faulting characteristic of the San Andreas stress province. Because both normal and strike-slip faulting occur at NTS, the magnitudes of the principal stresses have been inferred to be at the transition between normal and strike-slip stress regimes $\left(S_{v}=S_{H}>S_{h}\right)$. The few published regional focal mechanisms from events at depths from 0.8 to $10.2 \mathrm{~km}$ have almost exclusively strike-slip solutions (Figure 14).

The NW to WNW extension direction indicated by the regional data (Table 3) agrees very well with the $S_{h}$ direction of $\mathrm{N} 60^{\circ} \mathrm{W}$ to $\mathrm{N} 65^{\circ} \mathrm{W}$ seen in the Yucca Mountain drill holes. The magnitudes of $S_{h}$ measured by the hydraulic fracturing technique are also close to the value of $S_{h}=1 / 2 S_{v}$ determined by McGarr [1982] to be characteristic of the transition zone. However, at the depths of our measurements, Yucca Mountain is within a normal faulting stress regime, with $S_{H}$ about halfway between $S_{v}$ and $S_{h}$ in magnitude. This is significantly different from the stress regime with $S_{H}=S_{v}$ that has usually 

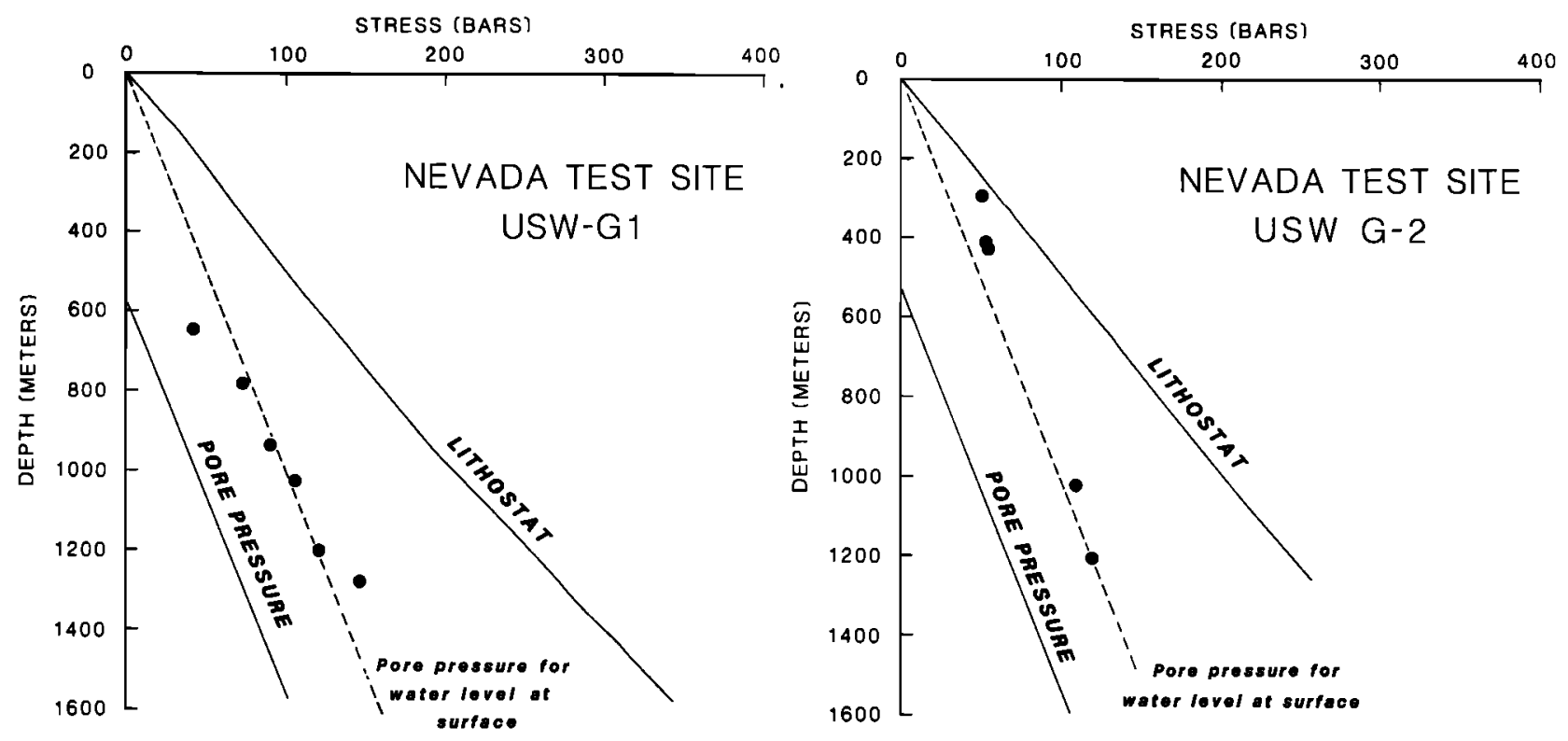

Fig. 13. Measured values of the least horizontal principal stress $S_{h}$ as a function of depth in USW G-1 and USW G-2. Pore pressure line corresponding to the observed water level in each hole is shown for reference. The dashed line is the pore pressure curve which would be expected if the hole were filled to the surface with water. The measured values of $S_{h}$ suggest that the fluid pressure in the hole may have exceeded $S_{h}$ during drilling, causing drilling-induced hydraulic fractures to form and propagate. Note that the upper three measurements in USW G-2 are upper limits on the value of $S_{h}$ (see text for discussion).

TABLE 3. Compilation of Stress Indicators, NTS Area

\begin{tabular}{|c|c|c|c|c|c|c|c|}
\hline No. & Location & $\begin{array}{c}\text { Type of } \\
\text { Measurement }\end{array}$ & $\begin{array}{c}S_{h} \\
\text { Direction }\end{array}$ & $\begin{array}{l}\text { Stress } \\
\text { Regime }\end{array}$ & $\begin{array}{l}\text { Age of } \\
\text { Indicator }\end{array}$ & Reference & Comments \\
\hline 1 & $\begin{array}{r}\text { Rainier } \\
\text { Mesa }\end{array}$ & hydrofrac & $\mathrm{N} 55^{\circ} \mathrm{W}$ & strike slip (ss) & 0 & $\begin{array}{l}\text { Haimson et al. } \\
\text { [1974] }\end{array}$ & $\begin{array}{l}\text { all of these measurements } \\
\text { may be strongly influenced } \\
\text { by topography }\end{array}$ \\
\hline 2 & $\begin{array}{l}\text { Rainier } \\
\text { Mesa }\end{array}$ & $\begin{array}{l}\text { hydrofrac (in } \\
\text { center of mesa) }\end{array}$ & NW-SE & normal/ss & $\mathbf{0}$ & $\begin{array}{l}\text { Smith et al. } \\
{[1981]}\end{array}$ & \\
\hline 3 & $\begin{array}{l}\text { Rainier } \\
\text { Mesa and } \\
\text { Aqueduct } \\
\text { Mesa }\end{array}$ & overcoring & $\begin{array}{l}\text { NW-SE to } \\
\text { E-W }\end{array}$ & $\begin{array}{l}\text { mainly ss } \\
\text { some normal }\end{array}$ & 0 & $\begin{array}{l}\text { Ellis and } \\
\quad \text { Magner [1980] }\end{array}$ & $\begin{array}{l}\text { all of the measurements } \\
\text { may be strongly influenced } \\
\text { by topography }\end{array}$ \\
\hline 4 & $\begin{array}{l}\text { Pahute } \\
\text { Mesa }\end{array}$ & $\begin{array}{l}\text { explosion produced } \\
\text { fractures in tuff }\end{array}$ & $\begin{array}{l}\text { WNW-ESE } \\
\text { to E-W }\end{array}$ & normal & 0 & Snyder [1971] & \\
\hline 5 & $\begin{array}{r}\text { Pahute } \\
\text { Mesa }\end{array}$ & borehole breakouts & $\mathrm{N} 50^{\circ} \mathrm{W}$ & $?$ & 0 & $\begin{array}{l}\text { Springer and } \\
\text { Thorpe [1981] }\end{array}$ & \\
\hline 6 & $\begin{array}{l}\text { Yucca } \\
\text { Flat }\end{array}$ & $\begin{array}{l}\text { explosion produced } \\
\text { fractures in } \\
\text { alluvium }\end{array}$ & $\mathrm{N} 50^{\circ} \mathrm{W}$ & normal & 0 & Carr $[1974]$ & $\begin{array}{l}\text { fractures in alluvium } \\
\text { likely to be affected } \\
\text { by basin structure }\end{array}$ \\
\hline 7 & $\begin{array}{r}\text { Yucca } \\
\text { Flat }\end{array}$ & borehole breakouts & $\mathbf{N} 60^{\circ} \mathbf{W}$ & $?$ & 0 & Carr [1974] & \\
\hline 8 & $\begin{array}{l}\text { Yucca } \\
\text { Flat }\end{array}$ & borehole breakouts & $\mathrm{N} 45^{\circ} \mathrm{W}$ & $?$ & 0 & $\begin{array}{l}\text { Springer and } \\
\quad \text { Thorpe [1981] }\end{array}$ & \\
\hline 9 & $\begin{array}{l}\text { Crater } \\
\text { Flat (east) }\end{array}$ & $\begin{array}{l}\text { trenching of } \\
\text { Quaternary faults }\end{array}$ & $\begin{array}{l}\mathrm{N}^{\circ} 0^{\circ}- \\
80^{\circ} \mathrm{W}\end{array}$ & $?$ & 0.1 m.y. & $\begin{array}{l}\text { Swadley and } \\
\text { Hoover [1984] }\end{array}$ & $\begin{array}{l}\text { exact displacement } \\
\text { direction unknown }\end{array}$ \\
\hline 10 & $\begin{array}{l}\text { Crater } \\
\text { Flat }\end{array}$ & $\begin{array}{l}\text { alignment of } \\
\text { cinder cones }\end{array}$ & $\begin{array}{r}\mathbf{N} 60^{\circ} \mathbf{W} \\
\pm 10^{\circ}\end{array}$ & normal & $1.1 \mathrm{~m} . \mathrm{y}$. & & $\begin{array}{l}\text { indicators are too old } \\
\text { and their orientation } \\
\text { may be related to pre- } \\
\text { existing fractures }\end{array}$ \\
\hline 11 & $\begin{array}{r}\text { Crater } \\
\text { Flat }\end{array}$ & dikes & $\begin{array}{l}\text { E-W to } \\
\text { WNW }\end{array}$ & normal & 3.75 m.y. & & $\begin{array}{l}\text { indicators are too old } \\
\text { and their orientation } \\
\text { may be related to pre- } \\
\text { existing fractures }\end{array}$ \\
\hline 12 & NTS area & $\begin{array}{l}\text { focal mechanism } \\
P \text { axes }\end{array}$ & $\mathrm{NW}$ to $\mathrm{W}$ & ss/normal & 0 & $\begin{array}{c}\text { Rogers et al. } \\
\text { [1983] }\end{array}$ & $\begin{array}{l}\text { uncertainty in relation- } \\
\text { ship between } P \text { axes and } \\
S_{h} \text { direction }\end{array}$ \\
\hline 13 & $\begin{array}{r}\text { Pahute } \\
\text { Mesa }\end{array}$ & $\begin{array}{l}\text { focal mechanism } \\
P \text { axes }\end{array}$ & $\mathrm{NW}$ to $\mathrm{W}$ & ss/normal & 0 & $\begin{array}{l}\text { Hamilton and } \\
\text { Healy }[1969]\end{array}$ & $\begin{array}{l}\text { uncertainty in relation- } \\
\text { ship between } P \text { axes and } \\
S_{\text {direction }} \text { diren }\end{array}$ \\
\hline 14 & $\begin{array}{l}\text { Yucca } \\
\text { Mountain }\end{array}$ & $\begin{array}{l}\text { drilling-induced } \\
\text { hydraulic fractures }\end{array}$ & $\begin{array}{l}\mathrm{N} 60^{\circ}- \\
\mathrm{N}^{\circ} \mathrm{O} \\
\end{array}$ & normal & 0 & this report & \\
\hline
\end{tabular}




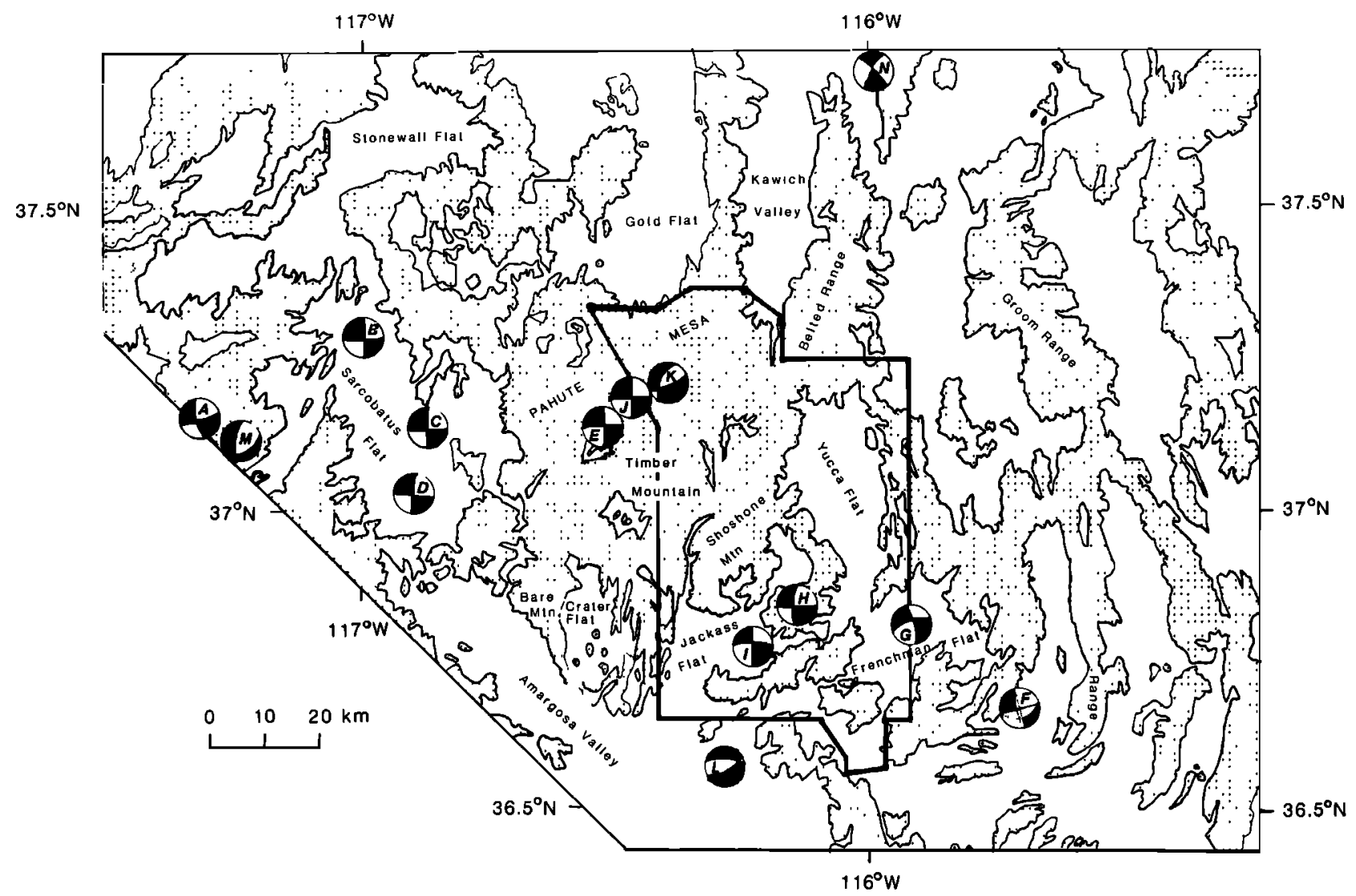

Fig. 14. Compilation of NTS region focal mechanisms. Letters correspond to event identification from Table 4.

been assumed for the area. Yucca Mountain could be locally anomalous, having a much lower relative magnitude of $S_{H}$ than most of the surrounding region. However, no change in stress regime is actually required by the presence of strike-slip faulting in the area.
The reported focal mechanisms do not have a uniform distribution of nodal plane orientations. The nodal planes are nearly all steeply dipping, with $\mathrm{N}$ to $\mathrm{NE}$ strike, and show strike-slip faulting, with minor normal component [Rogers et al., 1983]. Resolution of the Yucca Mountain stress tensor

TABLE 4. Focal Mechanisms Compiled for the NTS Region

\begin{tabular}{|c|c|c|c|c|}
\hline Event & Date & Depth, km & Location & Reference \\
\hline $\mathbf{A}$ & Jan. 23, 1981 & 10.2 & $\begin{array}{l}37.148^{\circ} \mathrm{N}, 117.387^{\circ} \mathrm{W} \\
\text { Gold Mountain }\end{array}$ & Rogers et al. [1983] \\
\hline B & Dec. 25,1979 & 8.1 & $\begin{array}{l}37.288^{\circ} \mathrm{N}, 114.062^{\circ} \mathrm{W} \\
\text { Sarcobatus Flat }\end{array}$ & Rogers et al. [1983] \\
\hline C & March 10, 1981 & 6.6 & $\begin{array}{l}37.155^{\circ} \mathrm{N}, 116.917^{\circ} \mathrm{W} \\
\text { Sarcobatus Flat }\end{array}$ & Rogers et al. [1983] \\
\hline$D^{*}$ & Aug. 17, 1979 & 9.2 & $\begin{array}{l}37.055^{\circ} \mathrm{N}, 116.955^{\circ} \mathrm{W} \\
\text { Sarcobatus Flat }\end{array}$ & Rogers et al. [1983] \\
\hline$E^{*}$ & Aug. 17, 1979 & 6.3 & $\begin{array}{l}37.185^{\circ} \mathrm{N}, 116.570^{\circ} \mathrm{W} \\
\text { Thirsty Canyon }\end{array}$ & Rogers et al. [1983] \\
\hline $\mathrm{F}^{*}$ & Dec. 26,1981 & 8.6 & $\begin{array}{l}36.725^{\circ} \mathrm{N}, 115.708^{\circ} \mathrm{W} \\
\text { Indian Springs }\end{array}$ & Rogers et al. [1983] \\
\hline $\mathbf{G}$ & April 2, 1980 & 1.4 & $\begin{array}{l}36.860^{\circ} \mathrm{N}, 115.961^{\circ} \mathrm{W} \\
\text { Frenchman Flat }\end{array}$ & Rogers et al. [1983] \\
\hline $\mathbf{H}$ & April 23, 1980 & 6.7 & $\begin{array}{l}36.874^{\circ} \mathrm{N}, 116.162^{\circ} \mathrm{W} \\
\text { Lookout Peak }\end{array}$ & Rogers et al. [1983] \\
\hline I & May 10,1980 & 0.8 & $\begin{array}{l}36.811^{\circ} \mathrm{N}, 116.267^{\circ} \mathrm{W} \\
\text { Jackass Flats }\end{array}$ & Rogers et al. [1983] \\
\hline $\mathbf{J}^{*}$ & Dec. 1968 & & $\begin{array}{l}\text { Aftershocks of } \\
\text { Benham explosion }\end{array}$ & Hamilton and Healy [1969] \\
\hline $\mathrm{K}^{*}$ & Dec. 1968 & & $\begin{array}{l}\text { Aftershocks of } \\
\text { Benham explosion }\end{array}$ & Hamilton and Healy [1969] \\
\hline $\begin{array}{l}\mathbf{L} \\
\mathbf{M}\end{array}$ & $\begin{array}{l}\text { Feb. } 12,1970 \\
\text { Sept. } 1970\end{array}$ & & $\begin{array}{l}36.60^{\circ} \mathrm{N}, 116.27^{\circ} \mathrm{W} \\
37.13^{\circ} \mathrm{N}, 117.32^{\circ} \mathrm{W}\end{array}$ & $\begin{array}{l}\text { Smith and Lindh [1978] } \\
\text { Smith and Lindh [1978] }\end{array}$ \\
\hline $\mathbf{N}$ & March 23, 1970 & & $37.75^{\circ} \mathrm{N}, 116.00^{\circ} \mathrm{W}$ & Smith and Lindh [1978] \\
\hline
\end{tabular}

*Composite mechanism. 
$\left(S_{v}>S_{H}>S_{h}\right.$, with $S_{h}$ oriented N65 $5^{\circ}$ and $S_{H}$ about halfway between $S_{h}$ and $S_{v}$ in magnitude) onto planes of the reported orientations indicates that the direction of maximum shear (expected direction of slip vector) on these planes would be close to horizontal, and could be parallel to the observed slip vectors (J. M. Stock, manuscript in preparation, 1985). Thus, if these nodal planes were preexisting faults, subjected to the Yucca Mountain stress regime, they could produce strike-slip focal mechanisms consistent with those observed.

Yucca Mountain itself has very few observed earthquakes, compared to surrounding areas of NTS [Rogers et al., 1983]. Although there are faults of known Quaternary displacement in the area, results of trenching, as of this publication date, indicate no conclusive evidence of Holocene offset [Swadley et al., 1984]. Given the available laboratory measurements showing values of $\mu$ of 0.6 to 0.9 [Morrow and Byerlee, 1984], the measured stresses at Yucca Mountain are near the limit of those required to cause slip on favorably oriented preexisting faults. Scatter in both the laboratory and the field data cannot preclude the possibility that stress values might reach the levels required to cause seismic or aseismic motion on the faults.

Brace and Kohlstedt [1980] showed that Byerlee's law describing the frictional behavior of rocks [Byerlee, 1978] correctly gives the limiting value of lithospheric stresses in all cases of measured in situ stresses to depths of at least $4 \mathrm{~km}$. In areas of active normal faulting, the magnitude of the least horizontal stress relative to the vertical stress can be shown to be controlled by the vertical stress and frictional stability of preexisting faults, at the limit expected from Byerlee's law [Zoback and Healy, 1984]. In such areas the minimum principal stress values measured from hydrofrac tests are very close to the values at which slip would occur on favorably oriented faults. The measurements at Yucca Mountain fit this pattern. Since active faulting is occurring throughout the NTS area, as shown by recent seismicity and Quaternary offsets, it is expected that $S_{h}$ and $S_{v}$ should follow the values of frictional stability expected from Byerlee's law. Therefore the direction of $S_{h}$ and the relative magnitudes of $S_{h}$ and $S_{v}$ measured at Yucca Mountain are probably typical of the general regional stress pattern.

\section{Conclusions}

Hydraulic fracturing stress measurements in holes USW G-1 and USW G-2 at Yucca Mountain show that both the least and greatest horizontal principal stresses ( $S_{h}$ and $S_{H}$, respectively) are less than the vertical stress $S_{v}$. The measured stresses correspond to a normal faulting regime with $S_{H}$ about halfway between $S_{h}$ and $S_{v}$. The observed magnitudes of $S_{h}$ and $S_{v}$ indicate that frictional sliding might be expected to occur on favorably oriented preexisting faults if the coefficient of friction along such faults were close to 0.6 . For coefficients of friction close to 1.0, all preexisting faults should be stable. Laboratory tests of the Yucca Mountain volcanic rocks yield coefficents of friction ranging from 0.6 to 0.9 , suggesting that some favorably oriented preexisting fault zones might experience frictional sliding under the measured stress conditions. Seismic and geological observations, however, argue otherwise.

Borehole televiewer observations of USW G-1 and USW G-2 reveal that the $S_{h}$ direction is $N 65^{\circ} \mathrm{W} \pm 10^{\circ}$, as determined by (1) the $\mathrm{N} 25^{\circ} \mathrm{E}$ to $\mathrm{N} 30^{\circ} \mathrm{E}$ strike of long, drillinginduced hydraulic fractures seen to $760 \mathrm{~m}$ depth in USW G-1 and $680 \mathrm{~m}$ depth in USW G-2 and (2) the average $\mathrm{N} 65^{\circ} \mathrm{W}$ orientation of borehole breakouts seen from 1050 to $1220 \mathrm{~m}$ in the USW G-2 televiewer log. Breakouts in USW G-1, seen from 1113 to $1202 \mathrm{~m}$, have an average orientation of $S 80^{\circ} \mathrm{W}$ and are believed to be affected by a local perturbation in stress direction in this zone (consisting of highly fractured flow breccia which is not present in USW G-2). Owing to limitations on drill rig time, no orientations of test-induced hydrofractures were obtained.

These measurements are in good agreement with other stress indicators from the Nevada Test Site which yield a NW-SE to WNW-ESE direction of $S_{h}$. Although both normal and strike-slip faulting patterns are observed at NTS, calculations of slip on preexisting faults show that the observed strike-slip focal mechanisms could occur in response to a normal faulting stress regime similar to that measured at Yucca Mountain.

Acknowledgments. We thank J. Svitek, D. Styles, J. Hennagan, and G. Zwart for invaluable help in the operation and maintenance of field equipment and Larry Mastin for discussions of breakout theory and observations. This work would not have been possible without the generous advice and assistance of Ray Escobedo, Wallace Hammer, and other personnel of Fenix and Scisson, Inc. Thoughtful reviews by A. McGarr, P. Segall, and W. F. Brace are greatly appreciated. J. M. Stock was partially supported by the Fannie and John Hertz Foundation. The work was performed in cooperation with the Nevada Operations Office of the U.S. Department of Energy under interagency agreement DE-AI08-78ET44802.

\section{REFERENCES}

Anderson, L. A., Rock property analysis of core samples from the Yucca Mtn. UE25a \# 1 borehole, Nevada Test Site, Nevada, U.S. Geol. Surv. Open File Rep., 81-1338, 1981.

Bell, J. S., and D. I. Gough, Northeast-southwest compressive stress in Alberta: Evidence from oil wells, Earth Planet. Sci. Lett., 45, $475-482,1979$.

Bell, J. S., and D. I. Gough, The use of borehole breakouts in the study of crustal stress, in Hydraulic Fracturing Stress Measurements, edited by M. D. Zoback and B. C. Haimson, pp. 201-209, National Academy Press, Washington, D. C., 1983.

Brace, W. F., and D. L. Kohlstedt, Limits on lithospheric stress imposed by laboratory experiments, J. Geophys. Res., 85, 6248-6252, 1980.

Bredehoeft, J. D., and S. S. Papadopulos, A method for determining the hydraulic properties of tight formations, Water Resour. Res., 16, 233-238, 1980.

Bredehoeft, J. D., R. G. Wolff, W. S. Keys, and E. Shuter, Hydraulic fracturing to determine the regional in-situ stress field, Piceance Basin, Colorado, Geol. Soc. Am. Bull., 87, 250-258, 1976.

Byerlee, J. D., Friction of rocks, Pure Appl. Geophys., 116, 615-626, 1978.

Carr, W. J., Summary of tectonic and structural evidence for stress orientation at the Nevada Test Site, U.S. Geol. Surv. Open File Rep., 74-176, 1974.

Carr, W. J., Volcano-tectonic history of Crater Flat, southwestern Nevada, as suggested by new evidence from drill hole USW VH-1 and vicinity, U.S. Geol. Surv. Open File Rep., 82-457, 1982.

Cooper, H. H., J. D. Bredehoeft, and I. S. Papadopulos, Response of a finite-diameter well to an instantaneous charge of water, Water Resour. Res., 3, 263-269, 1967.

Earlougher, R. C., Advances in Well Test Analysis, AIME Monogr., vol. 5, American Institute of Mining, Metallurgical, and Petroleum Engineers, Dallas, Tex., 1977.

Ellis, W. L., and J. E. Magner, Compilation of results of threedimensional stress determinations made in Rainier and Aqueduct mesas, Nevada, U.S. Geol. Surv. Open File Rep., 80-1098, 1980.

Gough, D. I., and J. S. Bell, Stress orientations from oil-well fractures in Alberta and Texas, Can. J. Earth Sci., 18, 638-645, 1981.

Gough, D. I., and J. S. Bell, Stress orientation from borehole wall fractures with examples from Colorado, east Texas, and northern Canada, Can. J. Earth Sci., 19, 1358-1370, 1982.

Haimson, B. C., and J. M. Avasthi, Stress measurements in anisotropic rock by hydraulic fracturing, Proc. U. S. Symp. Rock Mech., 15th, 135-156, 1975. 
Haimson, B. C., and C. Fairhurst, Initiation and extension of hydraulic fractures in rock, Soc. Pet. Eng. J., 7, 310-318, 1967.

Haimson, B. C., and C. Fairhurst, In-situ stress determinations at great depths by means of hydraulic fracturing, Proc. U.S. Symp. Rock Mech., 1lth, 559-584, 1970.

Haimson, B. C., J. Lacomb, A. H. Jones, and S. J. Green, Deep stress measurement in tuff at the Nevada Test Site, in Advances in Rock Mechanics, vol. IIa, pp. 557-561, National Academy of Sciences, Washington, D. C., 1974.

Hamilton, R. M., and J. H. Healy, Aftershocks of the Benham nuclear explosion, Bull. Seismol. Soc. Am., 59, 2271-2281, 1969.

Healy, J. H., S. H. Hickman, M. D. Zoback, and W. L. Ellis, Report on televiewer $\log$ and stress measurements in core hole USW-G1, Nevada Test Site, U.S. Geol. Surv. Open File Rep., 84-15, 1984.

Hickman, S. H., and M. D. Zoback, The interpretation of hydraulic fracturing pressure-time data for in-situ stress determination, in Hydraulic Fracturing Stress Measurements, edited by M. D. Zoback and B. C. Haimson, pp. 44-54, National Academy Press, Washington, D. C., 1983.

Hickman, S. H., J. H. Healy, and M. D. Zoback, In situ stress, natural fracture distribution, and borehole elongation in the Auburn geothermal well, Auburn, New York, J. Geophys. Res., 90, 5497-5512, 1985.

Hoffman, L. R., and W. D. Mooney, A seismic study of Yucca Mountain and vicinity, southern Nevada: Data report and preliminary results, U.S. Geol. Surv. Open File Rep., 83-588, 1983.

Hubbert, M. K., and D. G. Willis, Mechanics of hydraulic fracturing, J. Pet. Technol., 9, 153-168, 1957.

Hudson, J. A., A critical examination of indirect tensile strength tests for brittle rocks, Ph.D. thesis, Univ. of Minnesota at Minneapolis St. Paul, Minneapolis, 1971.

Maldonado, F., and S. L. Koether, Stratigraphy, structure, and some petrographic features of Tertiary volcanic rocks at the USW G-2 drill hole, Yucca Mountain, Nye County, Nevada, U.S. Geol. Surv. Open File Rep., 83-732, 1983.

Marvin, R. F., F. M. Byers, Jr., H. H. Mehnert, P. P. Orkild, and M. W. Stern, Radiometric ages and stratigraphic sequence of volcanic and plutonic rocks, southern Nye and western Lincoln counties, Nevada, Geol. Soc. Am. Bull., 81, 2657-2676, 1970.

Mastin, L. G., Development of borehole breakouts in sandstone, M.S. thesis, Stanford Univ., Stanford, Calif., 1984.

McGarr, A., Analysis of states of stress between provinces of constant stress, J. Geophys. Res., 87, 9279-9288, 1982.

McGarr, A., M. D. Zoback, and T. C. Hanks, Implications of an elastic analysis of in situ stress measurements near the San Andreas fault, J. Geophys. Res., 87, 7797-7806, 1982.

Morrow, C., and J. Byerlee, Frictional sliding and fracture behavior of some Nevada Test Site tuffs, Proc. U.S. Symp. Rock Mech., 25th, 467-474, 1984.

Olsson, W. A., and A. K. Jones, Rock mechanics properties of volcanic tuffs from the Nevada Test Site, Rep. SAND80-1453, Sandia Natl. Lab., Albuquerque, N. M., 1980.

Price, R. H., Analysis of rock mechanics properties of volcanic tuff units from Yucca Mountain, Nevada Test Site, Rep. SAND82-1315, Sandia Natl. Lab., Albuquerque, N. M., 1983.

Ratigan, J. L., A statistical fracture mechanics determination of the apparent tensile strength in hydraulic fracture, in Hydraulic Fracturing Stress Measurements, edited by M. D. Zoback and B. C. Haimson, pp. 159-166, National Academy Press, Washington, D. C., 1983.

Richardson, R. M., Hydraulic fracture in arbitrarily oriented boreholes: An analytic approach, in Hydraulic Fracturing Stress Measurements, edited by M. D. Zoback and B. C. Haimson, pp. 167-175, National Academy Press, Washington, D. C., 1983.

Rogers, A. M., S. C. Harmsen, W. J. Carr, and W. Spence, Southern Great Basin seismological data report for 1981 and preliminary data analysis, U.S. Geol. Surv. Open File Rep., 83-669, 1983.

Scott, R. B., and J. Bonk, Preliminary geologic map of Yucca Mountain with geologic sections, Nye County, Nevada, U.S. Geol. Surv. Open File Rep., 84-494, 1984.
Scott, R. B., and M. Castellanos, Stratigraphic and structural relations of volcanic rocks in drill holes USW GU-3 and USW G-3, Yucca Mountain, Nye County, Nevada, U.S. Geol. Surv. Open File Rep., 84-0491, 1984.

Smith, C., W. C. Vollendorf, and W. E. Warren, In-situ stress from hydraulic fracture measurements in G Tunnel, Nevada Test Site, Rep. SAND80-1138, Sandia Natl. Lab., Albuquerque, N. M., 1981.

Smith, R. B., and A. G. Lindh, Fault-plane solutions of the western United States: A compilation, Cenozoic Tectonics and Regional Geophysics of the Western Cordillera, Mem. Geol. Soc. Am., 152, 107-109, 1978.

Snyder, R. P., Composite potshot fracture map of Pahute Mesa, Nevada Test Site, Special Studies-86, U.S. Geol. Surv. Rep. USGS474-100, 1971

Snyder, D. B., and W. J. Carr, Interpretation of gravity data in a complex volcano-tectonic setting, southwestern Nevada, J. Geophys. Res., 89, 10193-10206, 1984.

Spengler, R. W., F. M. Byers, and J. B. Warner, Stratigraphy and structure of volcanic rocks in drill hole USW-G1, Yucca Mountain Nye County, Nevada, U.S. Geol. Surv. Open File Rep, 81-1349, 1981.

Springer, J. E., and R. K. Thorpe, Borehole elongation versus in situ stress orientation, Rep. UCRL-87018, Lawrence Livermore Lab., Livermore, Calif., 1981.

Stock, J. M., and J. H. Healy, Magnitudes and orientations of stresses in an extensional regime: Yucca Mountain, Nevada, Geol. Soc. Am. Abstr. Programs, 16, 669, 1984.

Stock, J. M., J. H. Healy, and S. H. Hickman, Report on televiewer $\log$ and stress measurements in core hole USW G-2, Nevada Test Site, U.S. Geol. Surv. Open File Rep., 84-172, 1984.

Swadley, W. C., D. L. Hoover, and J. N. Rosholt, Preliminary report on Late Cenozoic faulting and stratigraphy in the vicinity of Yucca Mountain, Nye County, Nevada, U.S. Geol. Surv. Open File Rep., 84-788, 1984.

Vaniman, D., and B. Crowe, Geology and petrology of the basalts of Crater Flat: Applications to volcanic risk assessment for the Nevada Nuclear Waste Storage Investigations, Rep. LA-8845-MS, Los Alamos Natl. Lab., Los Alamos, N. M., 1981.

Winograd, I. J., Radioactive waste disposal in thick unsaturated zones, Science, 212(4502), 1457-1464, 1981.

Zemanek, J., R. L. Caldwell, E. E. Glenn, S. V. Holcomb, L. J. Norton, and A. J. D. Straus, The borehole televiewer-A new logging concept for fracture location and other types of borehole inspection, J. Pet. Technol., 21, 702-774, 1969.

Zemanek, J., E. E. Glenn, L. J. Norton, and R. L. Caldwell, Formation evaluation by inspection with the borehole televiewer, Geophysics, 35, 254-269, 1970.

Zoback, M. D., and J. H. Healy, Friction, faulting, and in situ stress, Ann. Geophys., 2, 689-698, 1984.

Zoback, M. D., and S. Hickman, In situ study of the physical mechanisms controlling induced seismicity at Monticello Reservoir, South Carolina, J. Geophys. Res., 87, 6959-6974, 1982.

Zoback, M. D., D. Moos, L. Mastin, and R. N. Anderson, Well bore breakouts and in situ stress, J. Geophys. Res., 90, 5523-5530, 1985.

Zoback, M. L., and M. D. Zoback, State of stress in the conterminous United States, J. Geophys. Res., 85, 6113-6156, 1980.

J. H. Healy, Office of Earthquakes, Volcanoes, and Engineering, U.S. Geological Survey, Menlo Park, CA 94025

S. H. Hickman and J. M. Stock, Department of Earth, Atmospheric, and Planetary Sciences, MIT, Cambridge, MA 02139.

M. D. Zoback, Department of Geophysics, Stanford University, Stanford, CA 94305.
(Received August 17, 1984; revised May 22, 1985; accepted May 24, 1985.) 